\title{
Hydrocarbon generation potential of late cretaceous shales and carbonates in Hekimhan basin and genetic relationships with Karadere oil seep (Eastern Anatolia Region, Turkey)
}

\author{
Nazan Yalcin Erik ${ }^{1}$ (D)
}

Received: 1 November 2017 / Accepted: 10 May 2018 / Published online: 21 June 2018

(c) The Author(s) 2018

\begin{abstract}
In this study, Karadere oil seep (solid bitumen) and Late Cretaceous shales and carbonate levels of the Hekimhan Formation in Hekimhan Basin are compared genetically by means of organic-geochemical data. Investigated shale samples have generally low $(<0.5 \%)$ the total organic carbon values (TOC, wt $\%)$ and there is no petroleum and gas source-rock potential; however, the amount (0.11-5.92\%) and type (type II-III kerogen) of organic matter within limestone are consistent for source-rock potential. On the basis of average $T_{\max }\left(433{ }^{\circ} \mathrm{C}\right)$ and $0.53 \% R_{0}$ values, the investigated samples are at the immature and early mature level for hydrocarbon generation. According to biomarker data, the bitumen is pre-Cretaceous in age, highly reducing conditions, formed in a marine depositional environment at normal salinity, and under the influence of high bacterial activity, and was originate from an immature carbonate source rock. These geochemical data are highly in agreement with the late Cretaceous limestone of the Hekimhan Formation, and these rocks may be considered the source rock of the solid bitumen. However, these organic richness zones formed from non-indigenous organic material, and therefore, it is concluded that this seepage which generates from non-indigenous organic materials cannot be due to the limestone at the evaluated level. On the basis of organic-geochemical evaluations, it has been concluded that, in Hekimhan Basin, some hydrocarbons developed in deeper, more mature intervals of the limestone, and that these were migrated probably only a short distance within the basin and became really surfaced in relation to tension fractures.
\end{abstract}

Keywords Oil seeps $\cdot$ Solid bitumen $\cdot$ Eastern Anatolian region $\cdot$ Hekimhan Basin $\cdot$ Organic geochemistry

\section{Introduction}

The restricted Turkey's local energy resource, particularly fossil fuels in light of its growing energy claim have resulted in obedience on energy imports. At present, around $25 \%$ of the total energy demand is being met by local sources, while the rest is being supply from a different sources of imports. Turkey imports nearly $89 \%$ of its oil requirement (http:// www.mta.gov.tr/). The total petroleum reserve of Turkey is approximate fourty-two million tonnes (Korkmaz et al. 2008). Principally prolific oil fields are in the southeastern Turkey territory especially around Diyarbakır, Adıyaman, Raman and Garzan regions, and production is made from

Nazan Yalcin Erik

nyalcin@cumhuriyet.edu.tr

1 Cumhuriyet University of Depth of Geological Engineering, 58140 Sivas, Turkey the Paleozoic and Mesozoic aged formations (Korkmaz et al. 2008). In particular, due to limited fossil energy sources of Turkey petroleum and natural gas seepages create a remarkable point for research on this subject. The aim of this study is to evaluate the solid oil seep features in Hekimhan Basin, to estimate the possible source rock, and determine the genetic relationship together with organic geochemical evaluations.

Since the early periods of oil and gas exploration activities, hydrocarbon seeps (solid or liquid) have been considered as an important clue. Although it does not always show an oil accumulation of economic value, it has been considered as a sign that requires assessment for new exploration areas (Clarke and Cleverly 1991). Hydrocarbon seep is important in following the movement of oil that is generated by the source rocks or from underground reservoir towards surface, and therefore, for the estimation of the migration route and accumulation areas. The seeps of the hydrocarbon accumulations in bigger and continuous amounts on the sedimentations that are on the surface is defined as "Active 
Seep-macro seeps"; and the residues that are not observable as continuous flow on the surface are defined as "Passive Seeps-micro seeps" (Abrams 1996). Macro seeps may be monitored with petroleum, gas, bitumen traces, and asphalt; and micro seeps (such as La Brea tar pits, Los Angeles; Baku, Azerbaijan and Bermudez (Guannoco) Lake in Venezuela) may be monitored with various organic geochemical analyses and with the volatile or semi-volatile hydrocarbons or with hydrocarbon changes in the soil and sediments (Abrams 1996, 2005; van der Meer et al. 2002). For example, the Mescid-i Suleyman oil field and Gipssland Basin were discovered by making use of petroleum and gas seeps (Hunt 1996). As in this study, leaking oil can be observed in rock cracks or void fill and such residues are defined as solid bitumen (Jacob 1989). Solid bitumen ("migrabitumen") are secondary organic matter products that are filling voids and fractures in the rocks, and can occur within the source rocks and reservoir rocks in various basins around the world. The main reasons for their occurrence are the advanced thermal maturity and migration mechanism, mainly degradation (Curiale 1986). Many studies make it possible to better understanding to the solid bituminous origin and the thermal maturity of the sequences (Curiale 1986; Landis and Castaño 1995; George et al. 2007; Huc et al. 2000; Hwang et al. 1998; Kelemen et al. 2008, 2010; Petersen et al. 2013).

There are many important studies on the comparison of solid bitumen and source rock. For example; upper Jurassic-lower Cretaceous solid bitumen and bituminite properties of Chia Gara formation in the northern Iraq-Kurdistan region, Kirkuk oil field, were evaluated by Kus et al. (2016). The presence of oil spills and the association with solid bitumen in the cracks and spaces between the granules were stated to be a genetic relationship with the liquid hydrocarbon formation process of the Chia Gara formation. Another study was carried out by Gonçalves et al. (2015) at the sub-(Lusitanian Basin, Portugal). The middle Jurassic to Cretaceous sedimentary record in the Lusitanian Basin (Portugal) reveals the presence of disseminated solid bitumen. With the help of the results obtained by optical microscopy (fluorescence and reflection), three different solid bitumen types were identified and they corresponded to allochthonous (migrated) bitumens. According to this research, the presence of allochthonous bitumen indicates hydrocarbon formation and / or migration movements in the Lusitanian Basin or adjacent basins. In a study by Fink et al. (2016) the solid bitumens determined in the calcite cracks in the Natih Formation limestones in the Oman Mountains have been investigated in order to evaluate the oil migration mechanisms in this area. According to study, the solid bitumen formed in multiple events and were most likely derived from the Natih B source rocks. Additionally, the asphaltic solid bitumen was identified in the pore spaces of the middle Jurassic Khatatba sandstone reservoir in the Tut Field, Egypt
(Shalaby et al. 2012). Organic geochemical data indicate active non-biodegrade hydrocarbons in Khatatba sandstones. Also, biomarker data suggest that the bitumen originated from a marine shale source rock that was deposited in anoxic to suboxic conditions and the natural deasphalting is the dominant mechanism for the formation of the bitumen.

The investigated area located in Hekimhan Basin is between Eastern Anatolian Fault Zone (EAFZ) and Ecemiş Fault Zone (EFZ) in Eastern Anatolian Region (Fig. 1a). Bitumen was observed in the limestone, fractures-cracks and in the plaster in this area, and was defined as "Passive Seep". This area has been named as "Karadere Oil Seep" (Fig. 1b) for the first time in this study.

Hekimhan Basin has been the subject of many comprehensive general and economic-geological studies due to its rich underground resources (especially metallic minerals). Some studies on petroleum geology were conducted by Görmüş (1992), Gürer (1992), Gürer and Aldanmaz (2002), however they were not conducted in the present study area, and examined the city of Malatya and its surroundings (Ayan 1961; Ayyıldız and Önal 2005; Önal 2009). Among these, there are no studies examining Karadere oil seep, and the source rock potentials of upper-Cretaceous carbonates around Hekimhan district of Malatya city. The clue that appeared as seep of oil, which is an indispensable energy source, stance the subject matter of this study in the form of examining the sediments that might be the source rocks in detail.

\section{The geology of the Hekimhan basin}

The investigated area is located on the Southeastern Anatolia Edgefolds of the Anatolian Tectonic complex separated by Ketin (1966), and positioned in the southern side of the Anatolids and represents nearly $1000 \mathrm{~km}^{2}$ area (Fig. 1a). The Hekimhan Basin formed as part of the northern margin of the Taurides during the collision of the Inner Tauride Ocean and the İzmir-Ankara-Erzincan ocean (Fig. 1a). The units in this area have mainly folded and fractured structure because of being influenced by Alpine Orogenesis. A constant sedimentary sequence has been loaded on the overthrusts that occurred in the Late Kimmeridge Phase of Early Alpine Orogenesis, starting from Maastrichtian until Upper Miocene begining. Campanian-Maastrichtian aged transgressive and regressive series present the common crop area (Şengör and Y1lmaz 1981; Booth et al. 2014). This basin has been precipitated together with shallow marine and continental sedimentation, which is the case in the other basins of Central Anatolia, which reflects the clastic and carbonate precipitation in common. Maastrichtian sediments, which are rich in detritics, and coral reef limestone that contain rudist 


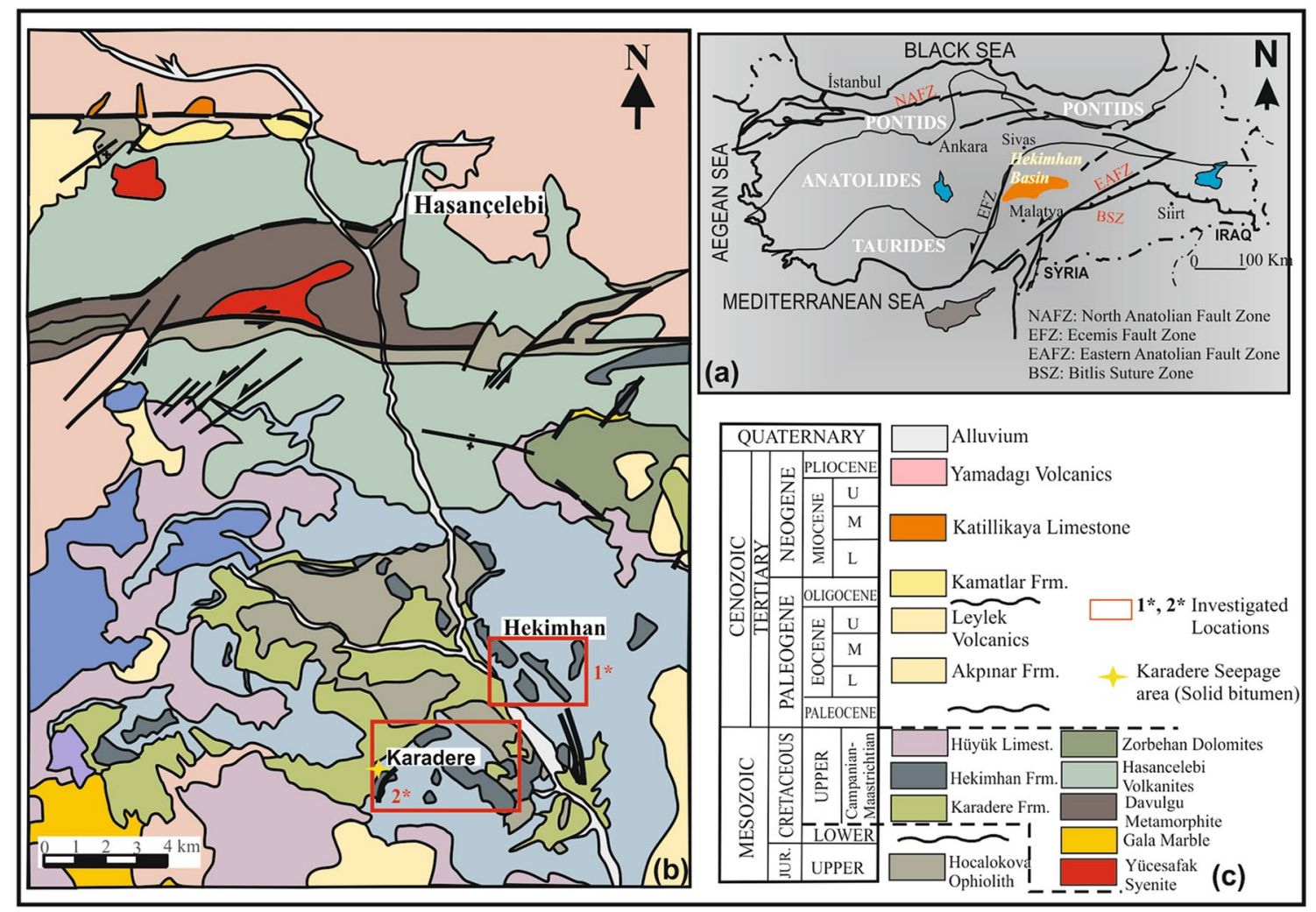

Fig. 1 Simplified geological map (modified from Gürer 1992) and location of the study area within the Anatolian Tectonic Complex, with sample locations

(Hippurites $\mathrm{sp}$.) show the precipitation process of the basin in early periods (Gürer 1992).

According to the general stratigraphic properties of the study area, the Hocalıkova ophiolite, which is in the base, consists of dunite, harzburgite, pyroxenite, gabbro, spilite and pelagic sediments, and possibly originated from internal Torids Ocean on the North. This unit is obducted as improper by braided stream, deltaic Karadere formation deposited in marine, and with upper Campanien pebble-sandstone-mudstone alternation; and lateral and vertical transition with the Hekimhan Formation, which is precipitated in shelf conditions in the upper level. There are the Hasançelebi Volcanites on the upper side. The upper-Cretaceous sequence, which progresses with Hüyük Limestone (Gürer 1992) and Zorbehan Dolomite, is in obduction position improperly in northern areas, and with Akpınar Formation, which is precipitated in shelf-lagoon depositional environment in southern areas that are as old as Paleocene-Mid-Eocene. The lower levels of the Hüyük limestone sequence have medium-thick layers, and the upper levels have multi-layers or are massive. This sequence was settled in the extremely stationary basin in tectonic terms in upper Cretaceous period, and developed in pelagic fossils rich biomicrite facies. Zorbehan Formation consists mainly of medium-thick layered dolomitic limestone. The Davulgu metamorphite was formed around the Yücesafak syenitoid, which moved towards inside of Hasancelebi Volcanites in Upper Maastrichtian. Leylek Volcanites and the diorite in the Upper Eocene, and the Gala Marble contact diorite. The Oligocene-lower Miocene Kamatlar Formation covers all units before it with unconformity. The Katillikaya limestone precipitated in Middle Miocene, and the upper Miocene-Pliocene Yamadag volcanites, which consist of pyroclastic and lava were placed on the sequence (Gürer 1992) (Fig. 1c).

Hekimhan Formation, which has been assessed in detail in terms of source rock potential, consists of pebble with sandstones, limestone, sandstones, and sandstone-marl-shale alternation on top of them (Fig. 3a). Lenticular limestone is observed mainly in the lower levels, and olistostromal and channel filling pebbles at various levels together with clayey limestone are observed in the upper levels (Gürer 1992). The formation is extremely rich in benthic and pelagic foraminifera, rudist etc. pelecypods; and is as old as upper Cretaceous-Maastrichtian according to paleontological data (Gürer 1992). The bitumen trace in the study area is observed in the surface as flow trace and solidified bitumen in nearly $45-50 \mathrm{~cm}^{2}$ area; and in filling and cracks in nearly $1 \mathrm{~cm}$ fracture (Fig. 2a, b). In petrographic 

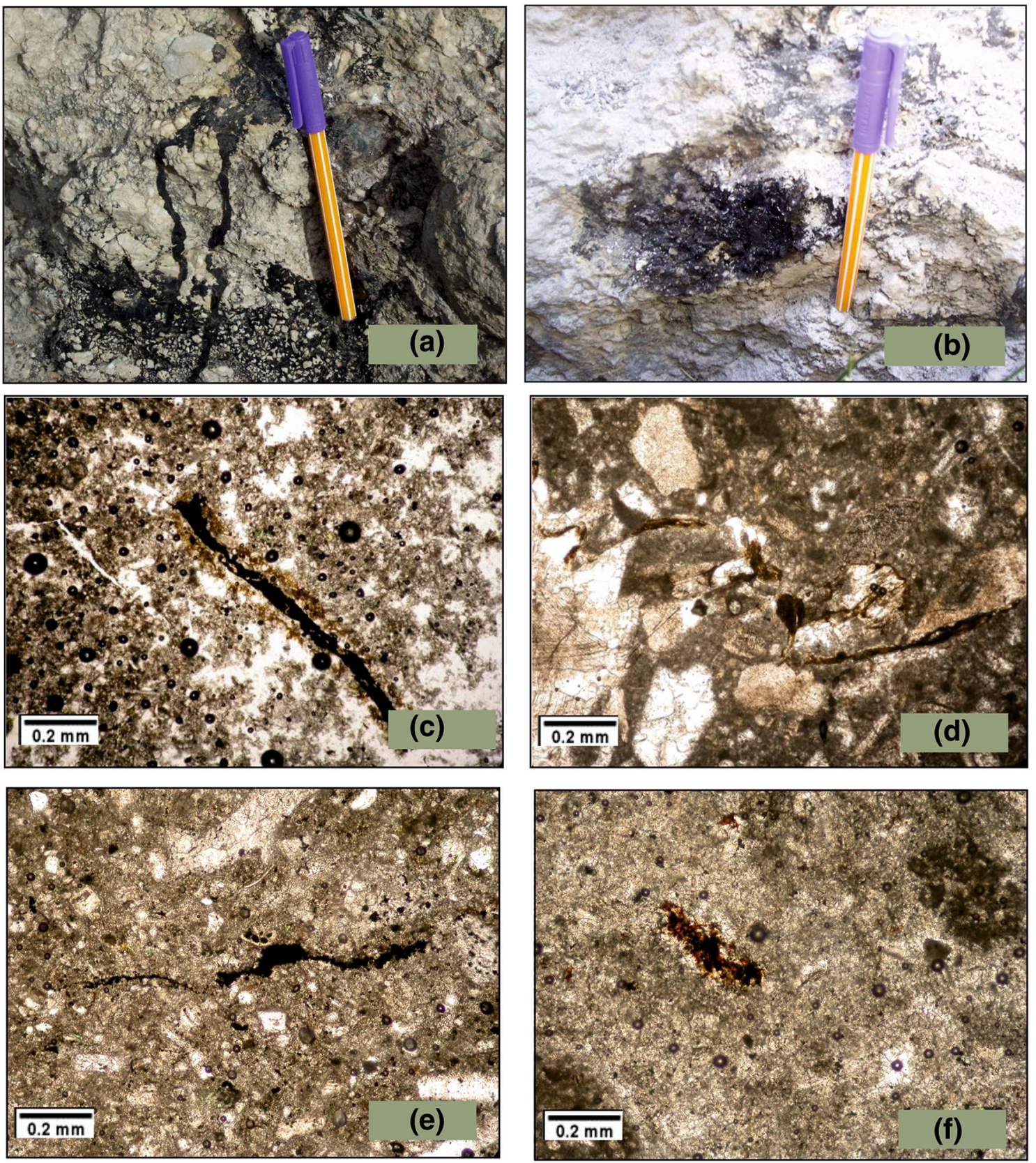

Fig. 2 Macroseeps and solid bitumen of the study area (a, b) and microseeps in petrographic thin-sections made from limestone specimens (c-f)

examinations, fracture filling and scattered microscopic bitumen traces attract attention especially in limestone samples that are close to seep area (Fig. 2c-f).

\section{Materials and methods}

The upper-Cretaceous Hekimhan Formation has been assessed with surface samples taken from two different locations (Fig. 2a). A total of 150 surface samples were collected at different locations from investigated area. Principally dark-grey, greenish-grey shales and alternated limestone were sampled and assessed as "Location 1" (L-1); the limestone and shales around Karadere Village were assessed as "Location 2" (L-2); and the bitumen/solidified oil on the rocks (MH-30), especially the solid bitumen scratched from the rocks, and the bitumen in the cracks of the rocks were assessed as MH-29 sample (Figs. 2b, 3b, respectively).

Rock-Eval/TOC analyses were done on 25 samples using Rock-Eval 6 instrument (Turkish Petroleum Laboratories, Ankara). The bulk mineralogical compositions and clay fraction mineralogy of samples were determined using a Rigaku 


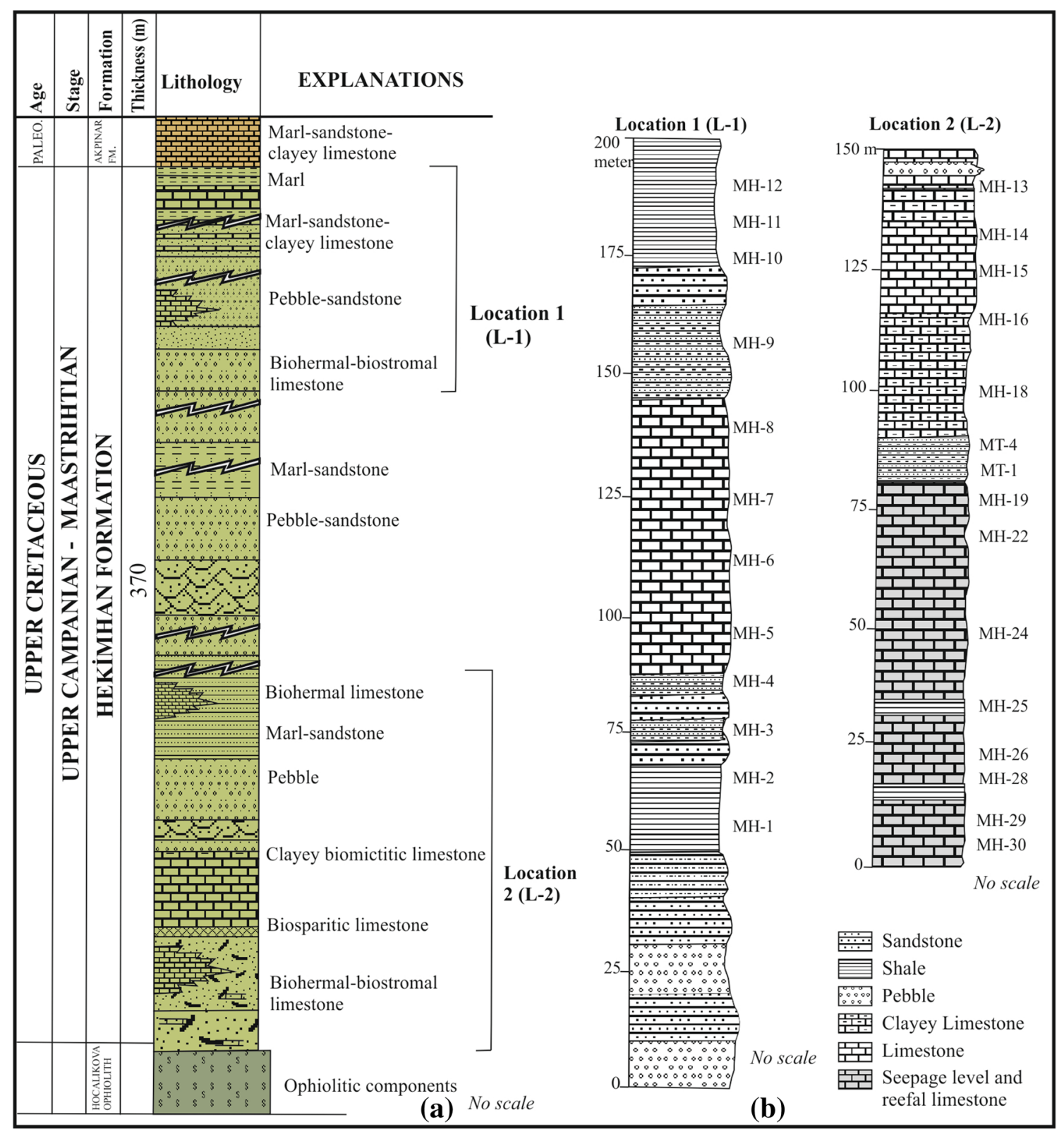

Fig. 3 Stratigraphic columnar sections of the Hekimhan Formation (modified from Gürer 1992) and sampled measured sections (locations 1 and 2)

DMAX IIIC X-ray diffractometry equipment (Cumhuriyet University laboratories, Sivas). Polished blocks were done from selected ten samples for organic petrographical determinations and huminite reflectance $\left(R_{0}\right)$ evaluation. These analyses were performed with a Leitz MPV-Spectra microscope $(546 \mathrm{~nm})$ using reflected white light. Also, especially in shale samples (45 samples) kerogen was isolated using Durand and Nicaise (1980)'s standard palynological preparation procedures.

Some shale and carbonaceous samples ( $>0.5$ TOC) were applied with solvent extraction liquid chromatography gas chromatography (GC) and gas chromatography-mass spectrometry (GC-MS) analyses were done on bulk extracts obtained from four bituminous samples. The aliphatic components acquired by chromatographic fractionation were done according to ASTM (D 5307-97, 2002) by Agilent 6850 instrument. Steran and terpan ratios were computed by integration of peak highs from the $\mathrm{m} / \mathrm{z} 217$ (for steranes) and $m / z 191$ (for terpanes) mass fragmentograms. Biomarker analyses were done in the research laboratories of the Turkish Petroleum Corporation (TP Research Group, Ankara). Furthermore, stable carbon isotopic $\left(\delta^{13} \mathrm{C}\right)$ values for the samples (eight whole rock sample) were measured on homogenized portion of rock sample using GV Instruments 
Isoprime EA-IRMS equipment according to PDB Standard (TP, Ankara, Turkey).

\section{Results}

\section{Organic geochemical investigations}

Total organic carbon value (wt\%) varies between $0.13-0.54 \%$ in the grey, greenish grey-brown shale and limestone samples that were taken from Location 1 (L-1); and is extremely low in shales (avg. $0.20 \%$ ) in the unit, and relatively higher (avg. $0.30 \%$ ) in the alternated limestone. The TOC values in the Location 2 (L-2), which is close to the seep area, vary between 0.11 and $0.12 \%$ in shale samples and $0.11-5.92 \%$ in limestone. As it is the case in sample MH-8 in L-1, the extractable hydrocarbon amounts are low (217 ppm) in the samples that are poor in organic matter, and extremely higher in the limestone in the L-2 (13,456-91,137 ppm) (Table 1).

The type of the organic matter, which is an important parameter for hydrocarbon generation potential, is determined mainly with Rock Eval pyrolysis. The hydrogen index (HI) values vary between 0 and $19 \mathrm{mg} \mathrm{HC} / \mathrm{g}$ TOC in L-1, the oxygen index (OI) values vary between 96 and $442 \mathrm{mg}$ $\mathrm{CO}_{2} / \mathrm{g}$ TOC. In L-2 samples, on the other hand, the $\mathrm{HI}$ is between 0 and $653 \mathrm{mg} \mathrm{HC/g}$ TOC, the OI is between 6 and $291 \mathrm{mgCO}_{2} / \mathrm{g}$ TOC. In HI- $T_{\max }$ diagram (Mukhopadhyay et al. 1995), all of the samples taken from L-1 are distributed in type III area (terrestrial, residue organic matter). The limestone samples in L-2 are observed in type II-III kerogen, which is mostly close to type II, and the shale samples are observed in type III area (Fig. 4). This conclusion is supported by palynological investigations on kerogen slide, because of amorphous and herbaceous materials are predominant (Fig. 5a).

The $T_{\max }$ value, which is used commonly to assess the sedimentary rocks in terms of organic maturation (Tissot and Welte 1984), varies between 423 and $496{ }^{\circ} \mathrm{C}$ in L-1 samples, and 416 between $474{ }^{\circ} \mathrm{C}$ in L-2 samples (Table 1 ). In $\mathrm{HI}-T_{\max }$ diagram, the limestone samples from L-2 are distributed in the immature-early mature, and the shale samples from L-1 are distributed in immature-mature zone (Fig. 4). The high $T_{\max }$ values determined especially in L-1 might have developed due to the clay content of the samples and due to the low levels of organic matter. Since there are no samples that are $\mathrm{S} 2$ value $>0.2$, it will not be proper to use the $T_{\max }$ data for maturity assessment (Table 1) (Peters 1986; Waple 1985). The clay mineral determined in 30-45\% rate in especially $\mathrm{MH}-1,2,4,6$ and 9 samples caused the formation of high $T_{\max }$ values like $450-496{ }^{\circ} \mathrm{C}$ in this sample. The production index (PI) has also been used in maturity assessments, and is higher than 0.1 in number 1 and 2 location samples; and shows mature phase (Table 1; Fig. 6); however, due to the migrated hydrocarbon existence in these samples, the PI parameter alone is not sufficient for maturity (Peters and Moldowan 1993). Generally, with the developing maturity, the bitumen/TOC ratio also increases (Tissot and Welte 1984); and the oil formation occurs between 0.05 and 0.1 range, and lower levels show immature rocks (Peters and Moldowan 1993). High bitumen/TOC ratio was determined in the limestone and organic matter rich shale samples were examined in location 2 ; however, low $T_{\max }$ values were detected showing pollution or migrated hydrocarbon existence rather than maturity phase (Table 1 ; Fig. 7). The huminite reflection values $\left(R_{0}, \%\right)$ at the rate of $0.49-0.53 \%$ in the shale samples in L-1, and between 0.50 and $0.55 \%$ in the shale samples in L-2 show immature-early mature phase (Table 1). When these data are compared with the $T_{\max }$ values, it is observed that low TOC value gives extremely different results from the other maturity parameters like huminite reflection and biomarker maturation data due to the hydrocarbons that are not indigenous and due to high clay content; and when the assessment is made based on one single parameter, it might produce significant mistakes.

\section{Hydrocarbon generation potential}

The S2/S 3 values of the samples from L- 1 are between 0 and 0.19 , and the values of the samples from L-2 are between 0 and 118.6 (Table 1). It is possible to claim that the Hekimhan Formation limestone have the potential of producing oil only in $\mathrm{L}-2$. The $\mathrm{S} 2 / \mathrm{S} 3$ values are extremely low $(0-0.19)$ in shale levels, and these samples do not have the potential of generating hydrocarbon Espitalié et al. (1985), Lafarqué et al. (1998) and Peters (1986).

The potential yield values (PY), vary between 0.0 and $49.29 \mathrm{mg} \mathrm{HC} / \mathrm{g}$ rock. Although this value is extremely low in the samples taken from L-1, they are extremely high in the limestone in L-2 (8.76-49.29 mg HC/g rock) (Table 1). Production Index values that are higher than 0.1 ; low $T_{\max }$, and bimodal S2 peak when compared with the rocks in the areas. For this reason, only high $\mathrm{HI}$ and TOC values do not provide accurate results about the source rock potential, which is the case in these samples.

In the $T_{\max }-\mathrm{PI}$ diagram, it is observed that the samples from L-1 are immature, and distributed in hydrocarbon generation also in non-indigenous areas (Fig. 6). Due to high $T_{\max }$ values, although some of the samples (MH-1, 2, 5 and 6 ) are observed in hydrocarbon generation areas, organic geochemical properties especially organic matter amounts and types are not proper for source rock potential. The majority of the samples from L-2 are distributed in nonindigenous hydrocarbon area, and the shales that contain less organic matter are distributed in immature and residue 


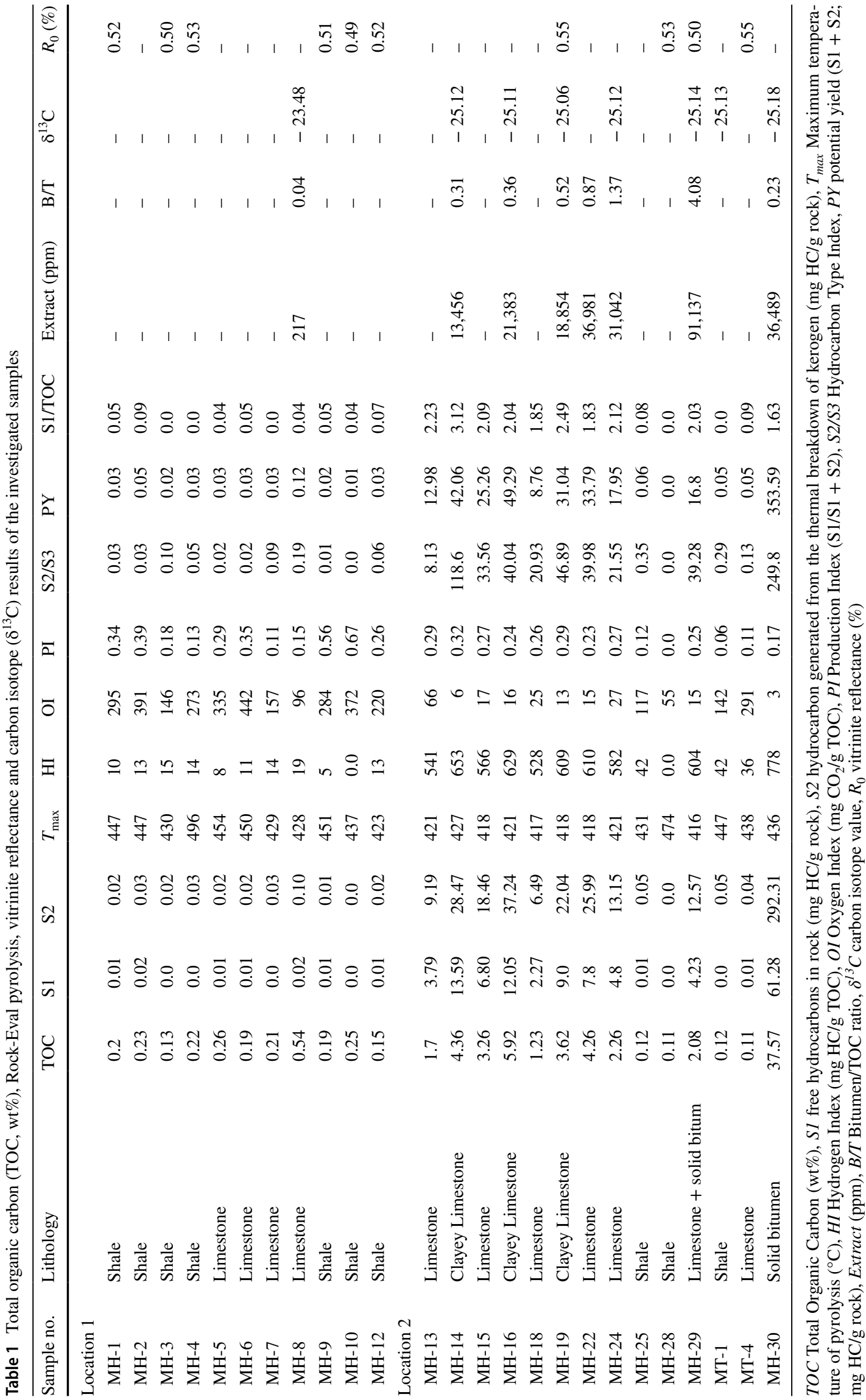




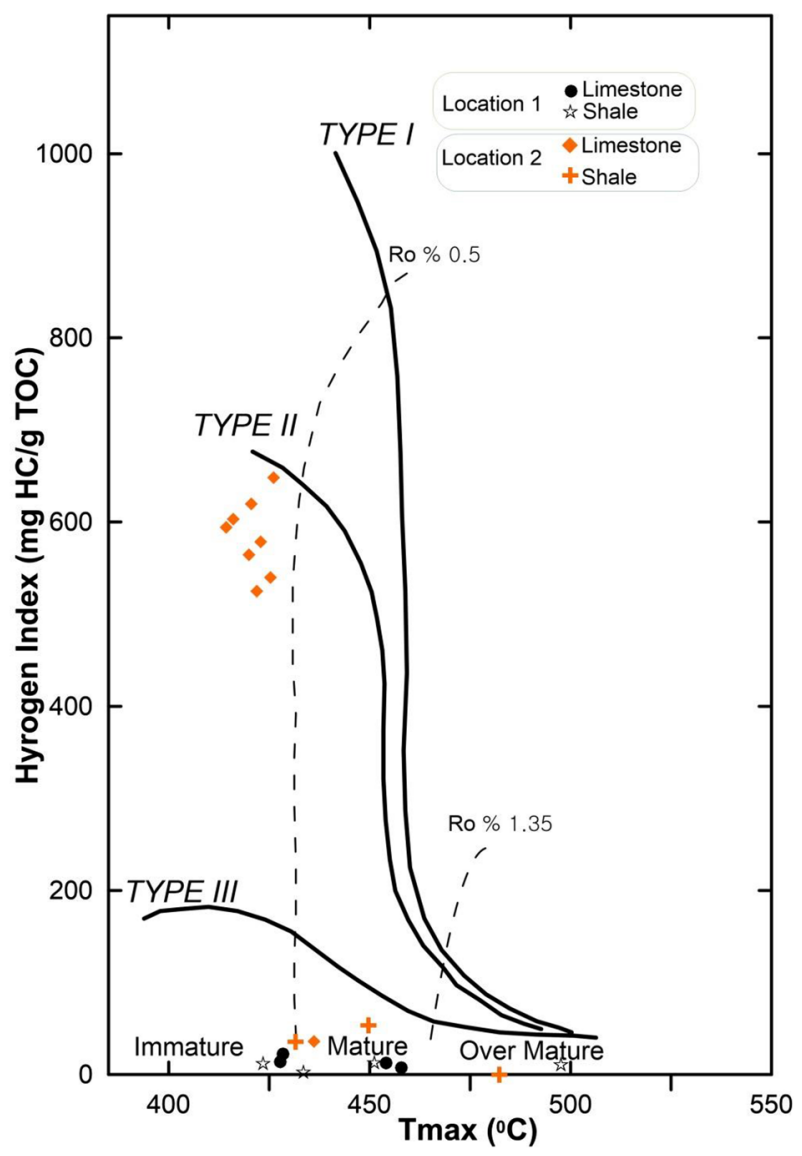

Fig. 4 Distribution of Hekimhan formation samples in the HI versus $T_{\max }$ diagram carbon area. The same result is also observed in TOC-total extract diagram (Fig. 7).

Especially, the organic richness levels in the samples that are examined show the non-indigenous (migrated) richness. For this reason, it is possible to claim that at least the limestone in Hekimhan formation that is sampled does not have source rock potential.

\section{Molecular composition}

The gas chromatography (GC) and gas chromatography-mass spectrometry (GC-MS) and thin layer chromatography (TLC) analyses of the Karadere solid bitumen, bituminous limestone, shale and limestone samples from the Hekimhan Formation have been performed; and using the obtained data, the basic similarities and differences in terms of their origins between the bitumen and the extracts of the other samples have been defined. However, especially the alteration effects of the bitumen sample and the migrated hydrocarbon effects in the other samples have been considered during the assessments.

\section{Isoprenoids and $n$-alkanes}

The total extract ratio of the analyzed samples varies between 217 and $91137 \mathrm{ppm}$, and is extremely high especially in the limestone in L-2 (Table 2). Polar, asphaltene and aromatic compounds are dominant in the investigated samples, and the level of saturated hydrocarbons is relatively less $(20-21.35 \%)$. Aromatic hydrocarbons are at the rate of $17-30 \%$, and $\mathrm{NSO}+$ polar compounds are at the rate of $52-68 \%$. With the atmospheric influence on the bitumen sample or with its biodegradation (water, bacteria etc.), the components in gas chromatograms are not separated
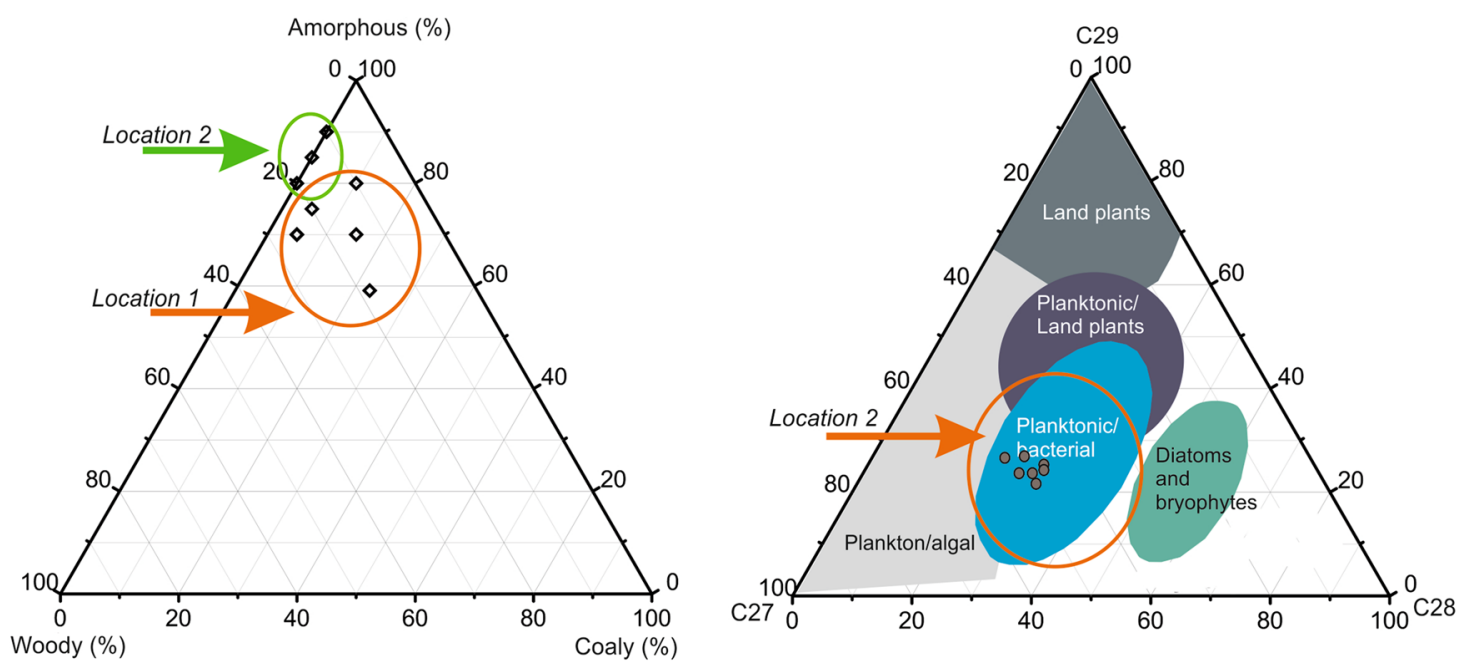

Fig. 5 Ternary diagrams showing organic-petrographic composition and the distribution of $\mathrm{C}_{2 \mathrm{~T}}-\mathrm{C}_{28}-\mathrm{C}_{29}$ regular steranes 


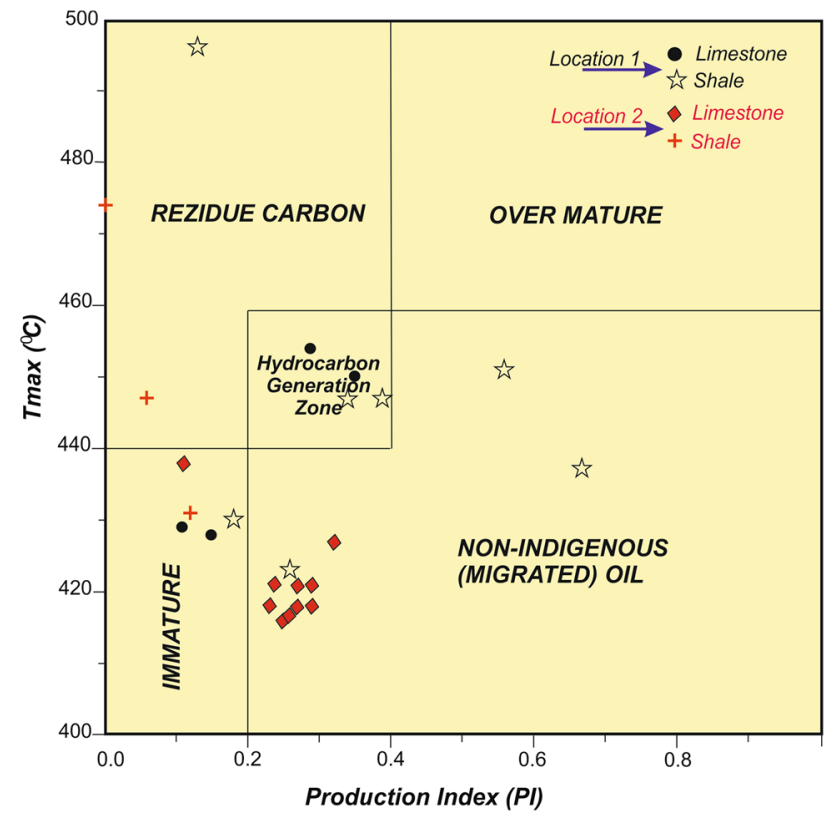

Fig. 6 Distribution of the studied samples in the $T_{\max }$ versus PI diagram (Katz 1995)

completely, and "humps" have been observed formed by these non-separated components (Fig. 8). The odd-numbered and even-numbered $n$-alkanes ranges between the $\mathrm{C}_{15}$ and $\mathrm{C}_{27}$, which are among the definable components, are close to each other in terms of abundance; however, the ratios have not been calculated because the peak values were not separated completely. There are $n$-alkanes, especially shortchain $\left(<n-\mathrm{C}_{21}\right)$ and medium-chain $\left(n-\mathrm{C}_{21}-n-\mathrm{C}_{25}\right)$ as well as long-chain $n$-alkanes $\left(>n-\mathrm{C}_{25}\right)$ like $\mathrm{C}_{26}$ and $\mathrm{C}_{27}$, in clayey limestone (MH-14, -16 and -19). Medium-chain $n$-alkanes $\left(\mathrm{C}_{21}, \mathrm{C}_{22}, \mathrm{C}_{23}\right)$ are abundant in the $\mathrm{MH}-14$ sample when compared with the other samples, and show aquatic-seashore vegetation (Hunt 1996). The peak distribution in the biomarker area in chromatograms is at the lower maturity level when compared with $\mathrm{Pr} / \mathrm{Ph}$ (0.14), $\mathrm{Pr} / n-\mathrm{C}_{17}$ (0.39) and
$n-\mathrm{C}_{18}(0.58)$ rates. It is possible to claim that there are mostly sea algae and they are influenced by oxidation. However, these parameters alone are not sufficient for interpreting about the generation and maturity characteristics especially both of early-mature and biodegraded samples (Volkman and Maxwell 1986).

\section{Steranes and terpanes}

To ascertain the organic geochemical features of the aliphatic fractions, gas chromatography and gas chromatography-mass spectrometry analyses were realized on the studied samples. Sterane and terpane characteristics of bitumen were investigated for shale and host rock samples; peak definitions on $\mathrm{m} / \mathrm{z} 191$ and $\mathrm{m} / \mathrm{z} 217$ chromatograms are given in Figs. 9 and 10.

While the clayey limestone samples (MH-14, -16, -19) from the Hekimhan Formation contains high $\mathrm{C}_{29}$ $\left(\mathrm{C}_{29}>\mathrm{C}_{27} \geq \mathrm{C}_{28}\right)$, limestone and bitumen sample from location 2 (MH-22, -24, -29) contain high $\mathrm{C}_{27}$ sterane. Based on the triangle diagram of homolog $\mathrm{C}_{27}-\mathrm{C}_{28}-\mathrm{C}_{29}$ series that indicate the organic matter composition in petroleum and kerogen, abundance of $\mathrm{C}_{28}$ sterane indicates green algae and diatoms, abundance of $\mathrm{C}_{27}$ indicates red algae and planktons, and abundance of $\mathrm{C}_{29}$ sterane indicates high plants and red and green algae (Peters and Moldowan 1993). Among the samples inspected, while $\mathrm{C}_{29}$ content ratio is higher particularly in shale and biomicritic limestone samples, ratio of $\mathrm{C}_{27}$ is higher in biosparitic limestone (Fig. 5b). Biomarker compositions of the examined samples also imply presence of red algae, diatoms and zooplanktons (Hunt 1996; Dutta et al. 2013). It could be said that especially $C_{29}$ in the composition results from brown-blue green algae in addition to low terrestrial organic matter content (Volkman 1986, 1988; Bhattacharya and Dutta 2015). This data is coherent with the low ratio of woody and coaly organic matter determined in the organic petrographic evaluations (Fig. 5a). However, the lower Paleozoic and Precambrian sediments
Fig. 7 Source-rock potential rating for the studied samples, based on TOC and extracted organic matter

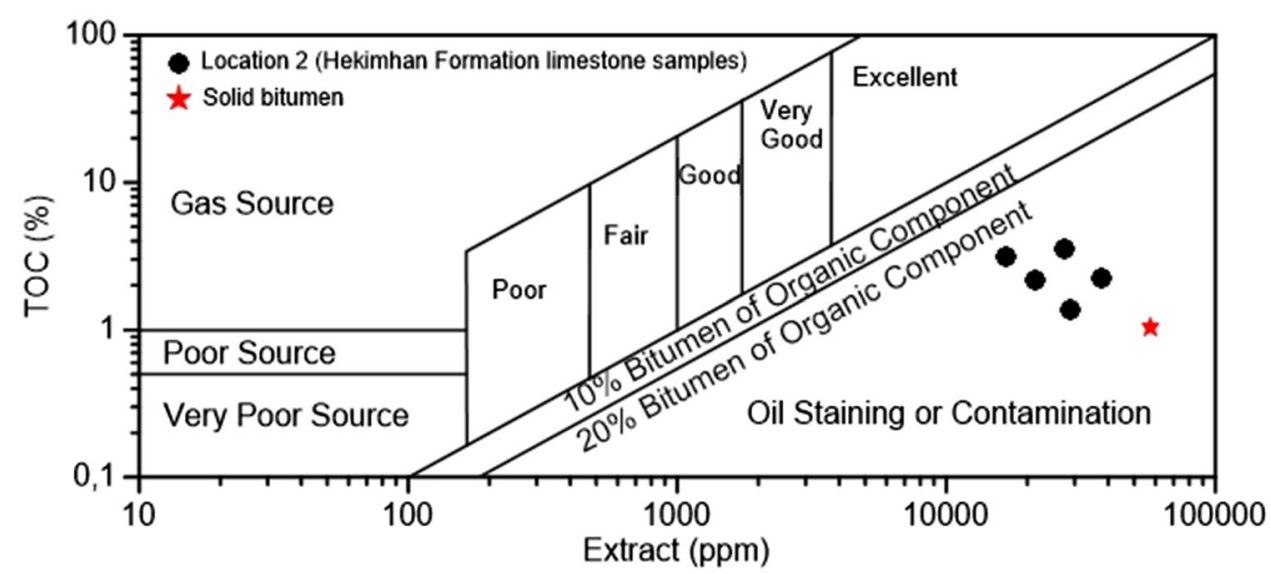


Table 2 Organic geochemical results and determined parameters of solid bitumen and extracts of examined samples

\begin{tabular}{|c|c|c|c|c|c|c|c|}
\hline \multirow[t]{2}{*}{ Parameters } & \multicolumn{7}{|c|}{ Sample no. } \\
\hline & MH-14 & MH-16 & MH-19 & MH-22 & MH-24 & MH-29 & MH-30 \\
\hline $\mathrm{Pr} / \mathrm{Ph}$ & 0.14 & - & - & - & - & - & - \\
\hline $\mathrm{Pr} / n-\mathrm{C}_{17}$ & 0.39 & - & - & - & - & - & - \\
\hline $\mathrm{Ph} / n-\mathrm{C}_{18}$ & 0.58 & - & - & - & - & - & - \\
\hline Diasterane/(diasterane + regular sterane) ratio, $\mathrm{C}_{27}$ & 0.47 & 0.29 & 0.60 & 0.19 & 0.29 & 0.27 & 0.23 \\
\hline$\beta \beta /(\beta \beta+\alpha \alpha)$ sterane RATIO $\left(\mathrm{C}_{29}\right)$ & 0.42 & 0.29 & 0.37 & 0.30 & 0.52 & 0.48 & 0.45 \\
\hline $20 \mathrm{~S} /(20 \mathrm{~S}+20 \mathrm{R})$ sterane ratio $\left(\mathrm{C}_{29}\right)$ & 0.39 & 0.29 & 0.32 & 0.30 & 0.53 & 0.49 & 0.43 \\
\hline $\mathrm{C}_{27} / \mathrm{C}_{29}$ sterane ratio & 0.46 & 0.24 & 0.52 & 0.62 & 1.57 & 1.28 & 1.34 \\
\hline $\mathrm{C}_{29} / \mathrm{C}_{30}$ sterane ratio & 0.69 & 1.84 & 2.76 & 3.01 & 2.53 & 2.51 & 2.51 \\
\hline $\mathrm{Ts} /(\mathrm{Ts}+\mathrm{Tm})$ ratio & 0.12 & 0.12 & 0.13 & 0.11 & 0.12 & 0.12 & 0.11 \\
\hline $22 \mathrm{~S} /(22 \mathrm{~S}+22 \mathrm{R})$ homohopane ratio $\left(\mathrm{C}_{31}\right)$ & 0.45 & 0.45 & 0.46 & 0.40 & 0.46 & 0.46 & 0.48 \\
\hline Moretane/Hopane ratio $\left(\mathrm{C}_{30}\right)$ & 0.31 & 0.31 & 0.31 & 0.31 & 0.19 & 0.20 & 0.25 \\
\hline C35 (22S)/C34 (22S) Hopane Ratio & 1 & 0.85 & 0.86 & 1 & 1 & 1 & 1 \\
\hline $\mathrm{C}_{23}$ (tricyclic terpane/ $\mathrm{C}_{23}$ tricyclic terpane $+\mathrm{C}_{30}$ Hopane) ratio & 0.75 & 0.63 & 0.73 & 0.57 & 0.77 & 0.76 & 0.68 \\
\hline Oleanane Index & - & - & 0.13 & 0.08 & - & - & - \\
\hline Diahopane/ $\mathrm{C}_{29}$ Ts ratio & 1.60 & 1 & 1.33 & 0.80 & 1.25 & 1.26 & 1.97 \\
\hline Sterane $/ 17 \alpha$ hopane ratio & 2.32 & 2.39 & 2.01 & 1.97 & 2.34 & 2.32 & 2.08 \\
\hline $\mathrm{C}_{35} /\left(\mathrm{C}_{31}-\mathrm{C}_{35}\right)$ Homohopane Index & 0.15 & 0.15 & 0.14 & 0.12 & 0.13 & 0.12 & 0.16 \\
\hline$\% \mathrm{C}_{27}, \% \mathrm{C}_{28}$ and $\mathrm{C}_{29}$ sterane ratios & $36,22,40$ & $15,22,63$ & $29,27,44$ & $40,25,35$ & $50,12,35$ & $49,13,35$ & $51,14,35$ \\
\hline$\% \mathrm{C}_{27}, \% \mathrm{C}_{28}$ and $\mathrm{C}_{29}$ diasterane ratios & $44,20,36$ & $31,24,45$ & $42,26,32$ & $39,24,37$ & $51,13,36$ & $50,14,36$ & $52,15,33$ \\
\hline $\mathrm{C}_{28} / \mathrm{C}_{29}$ sterane ratio & 0.70 & 0.71 & 0.76 & 0.72 & 0.75 & 0.73 & 0.76 \\
\hline $\mathrm{C}_{31}$ homohopane $(\mathrm{R}) / \mathrm{C}_{30}$ hopane & 0.83 & 0.5 & 0.89 & 0.44 & 0.52 & 0.51 & 0.54 \\
\hline $\mathrm{C}_{27} / \mathrm{C}_{29}$ Tricyclic terpane Ratio & 0.32 & 0.27 & 0.38 & 0.37 & 0.20 & 0.22 & 0.21 \\
\hline $\mathrm{C}_{24} / \mathrm{C}_{23}$ tricyclic terpane ratio & 0.39 & 0.39 & 0.39 & 0.40 & 0.41 & 0.41 & 0.43 \\
\hline $\mathrm{C}_{19} /\left(\mathrm{C}_{19}+\mathrm{C}_{23}\right)$ tricyclic terpane ratio & 0.23 & 0.21 & 0.18 & 0.16 & 0.24 & 0.23 & 0.14 \\
\hline $\mathrm{C}_{24}$ tetracyclic terpane/ $\mathrm{C}_{30}$ hopane ratio & 3.83 & 2.35 & 3.75 & 3.41 & 3.38 & 3.56 & 2.63 \\
\hline $\mathrm{C}_{26} / \mathrm{C}_{25}$ tricyclic terpane ratio & 0.20 & 0.25 & 0.18 & 0.30 & 0.33 & 0.32 & 0.33 \\
\hline Norhopane/Hopane ratio & 6.94 & 4.77 & 7.81 & 3.41 & 5.62 & 5.59 & 5.17 \\
\hline
\end{tabular}

contain $\mathrm{C}_{29}$ sterane at significant levels although there are no terrestrial plants (Grantham 1986; Rullkötter et al. 1986; Buchard et al. 1989). Matsumoto et al. (1982), and Fowler and Douglas (1984). Another approach is the destruction of $\mathrm{C}_{27}$ component in $\mathrm{MH}-14,-16$ and -19 numbered samples, in which the $\mathrm{C}_{29}$ component is observed more, because of bio-degradation and therefore the $\mathrm{C}_{29}$ steranes dominate (Table 2; Fig. 9).

The diasterane/sterane ratio is a beneficial parameter in comparing the source rocks with similar properties because this rate is influenced by maturity, lithology and the reduction conditions in depositional environment, especially in early-post mature phase (Waples and Machihara 1991). This ratio in the samples is between 0.19 and 0.60 , also 0.23 in the bitumen sample (Table 2). The $\mathrm{C}_{28} / \mathrm{C}_{29}$ sterane ratios generally are close to each other in all samples (0.70-0.76). Although $\mathrm{C}_{30} 5 \alpha(\mathrm{H}), 14 \beta(\mathrm{H}), 17 \beta(\mathrm{H})$ sterane is lower in $\mathrm{MH}-16$ and $\mathrm{MH}-22$ samples, they exist in all samples (Fig. 9). The sterane/hopane ratio being high ( $>2)$ shows the marine precipitation conditions (Moldowan et al. 1985;
Peters et al. 2005). In samples MH-19 and 22, the $18 \alpha(\mathrm{H})-$ oleanane index has been determined at extremely lower levels, and denominates terrestrial vegetation and suggesting Cretaceous or younger age.

The similar homohopane distributions in $\mathrm{m} / \mathrm{z} 191 \mathrm{chro-}$ matograms may suggest that these samples are similar in terms of their origins (Peters et al. 2005) (Fig. 10). $\mathrm{C}_{29} 17 \alpha$ $(\mathrm{H}), 21 \beta(\mathrm{H})$-norhopane is prevailing component in determined samples and in the bitumen. $\mathrm{C}_{24}$ tetracyclicterpane, $\mathrm{C}_{23}$ tricyclic terpanes are also considerable components. $\mathrm{C}_{30}$ hopanes and $\mathrm{C}_{35}$ homohopanes show the high bacterial effects and contribution in the samples (ten Haven et al. 1988).

$\mathrm{C}_{26} / \mathrm{C}_{25}$ tricyclic terpane ratio is commonly used to differentiate between marine and non-marine conditions, and shows that the samples precipitated in marine conditions (0.18-0.33) (Hanson et al. 2000). The existence of $\mathrm{C}_{35}$ homohopanes, hopane index $(<1)$, high $\mathrm{C}_{35} / \mathrm{C}_{34}$ homohopanes $(>0.8)$ also supports this result (Peters et al. 2005). The $\mathrm{C}_{31}$ homohopanes/ $\mathrm{C}_{30}$ hopanes ratio is $>0.25$ in marine 


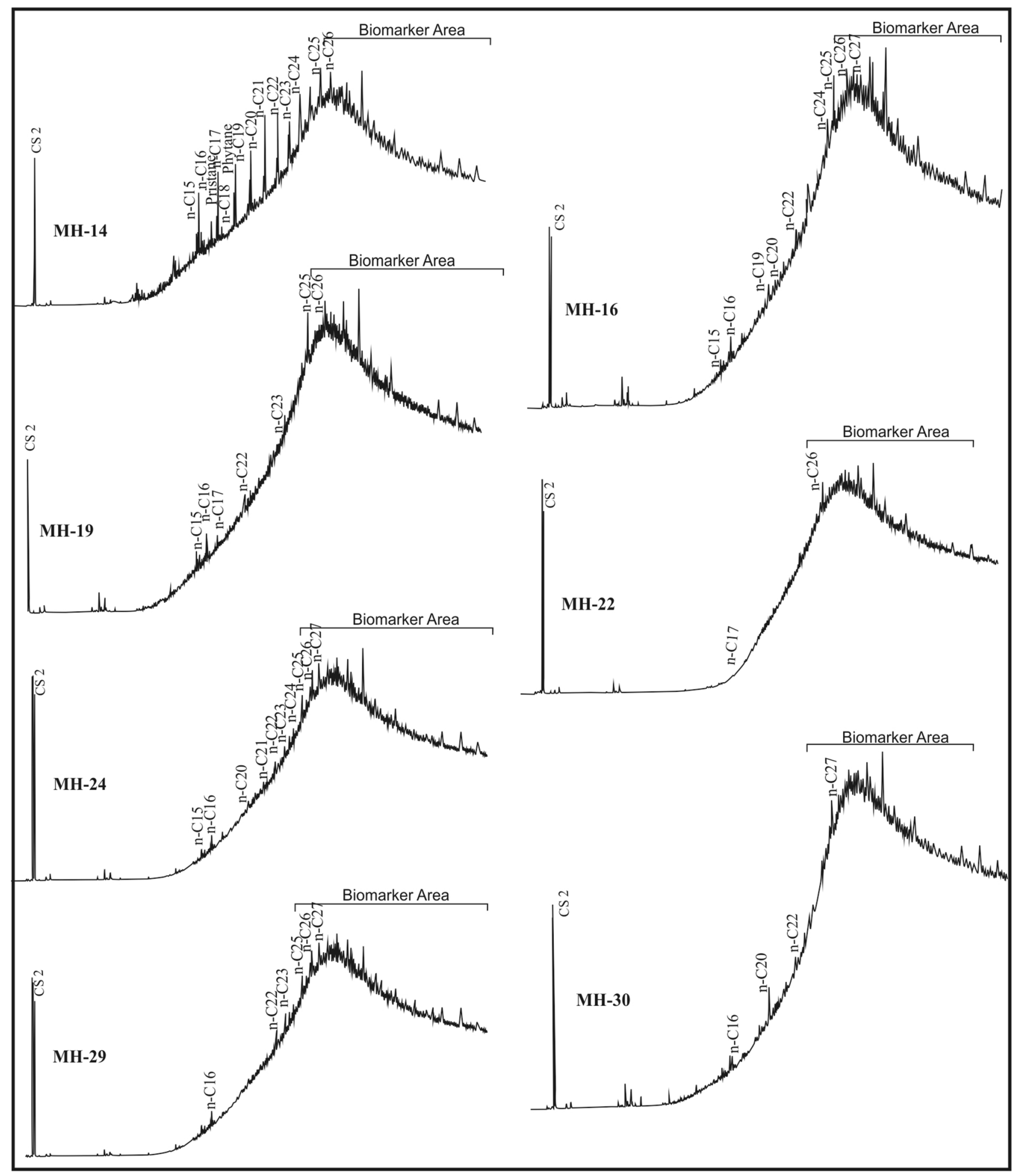

Fig. 8 Gas chromatograms of C15+ saturated hydrocarbons in extracts from Hekimhan Formation and bitumen samples

carbonates, marls and shale-type source rocks (Clark and Philp 1989), and between 0.44 and 0.89 in the samples that are analyzed indicate marine depositional conditions. The moretane/hopane (0.19-0.31), norhopane/hopane
(3.41-7.81), $\mathrm{C}_{24} / \mathrm{C}_{23}$ tricyclic terpane (0.39-0.41) and $\mathrm{C}_{19} /$ $\left(\mathrm{C}_{19}+\mathrm{C}_{23}\right.$ tricyclic terpane) (0.16-0.24) ratios (Fig. 10; Table 2) show the carbonate depositional conditions and related lithology (Peters et al. 2005). 


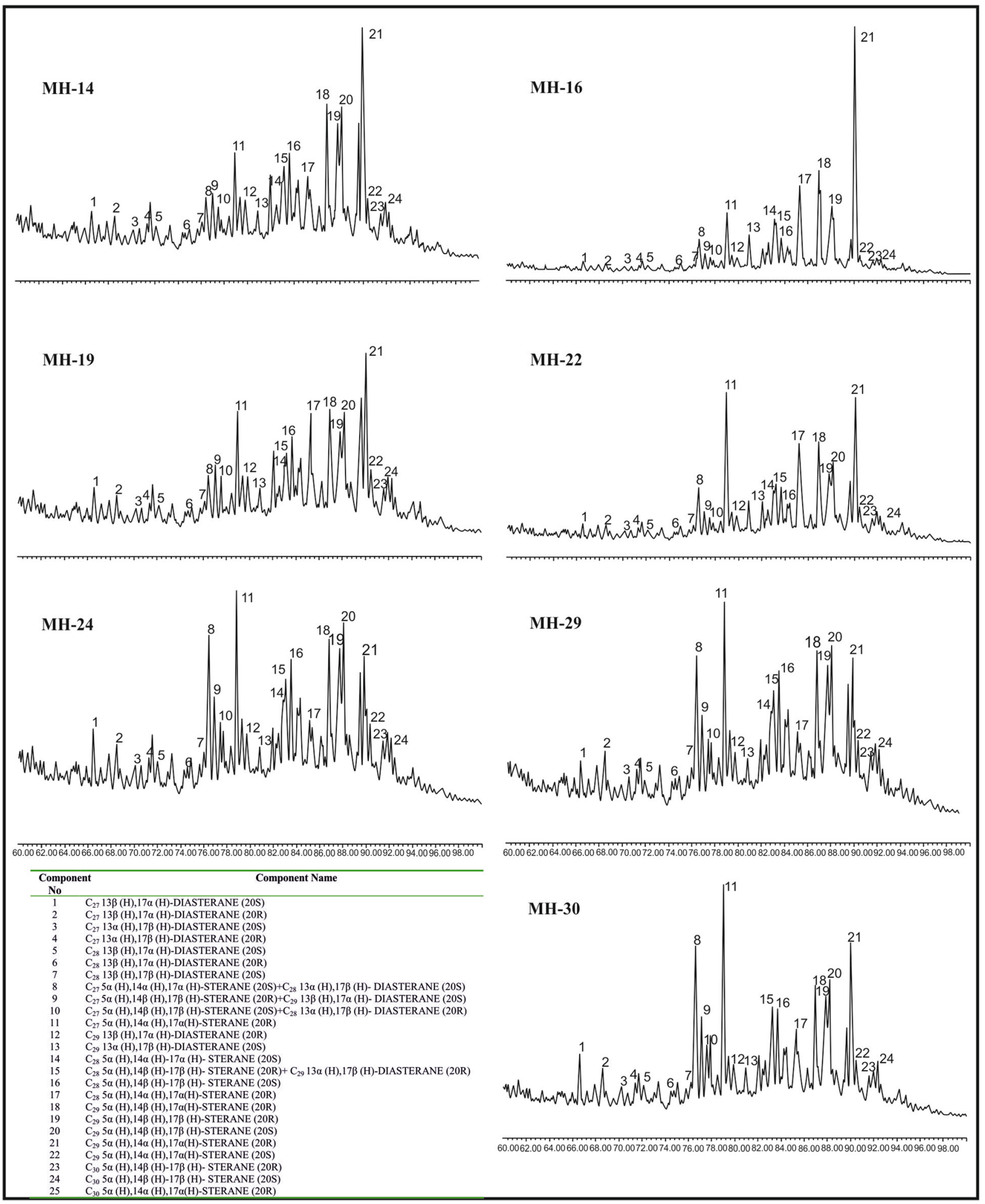

Fig. $9 \mathrm{~m} / z, 217$ mass chromatograms for the studied samples 

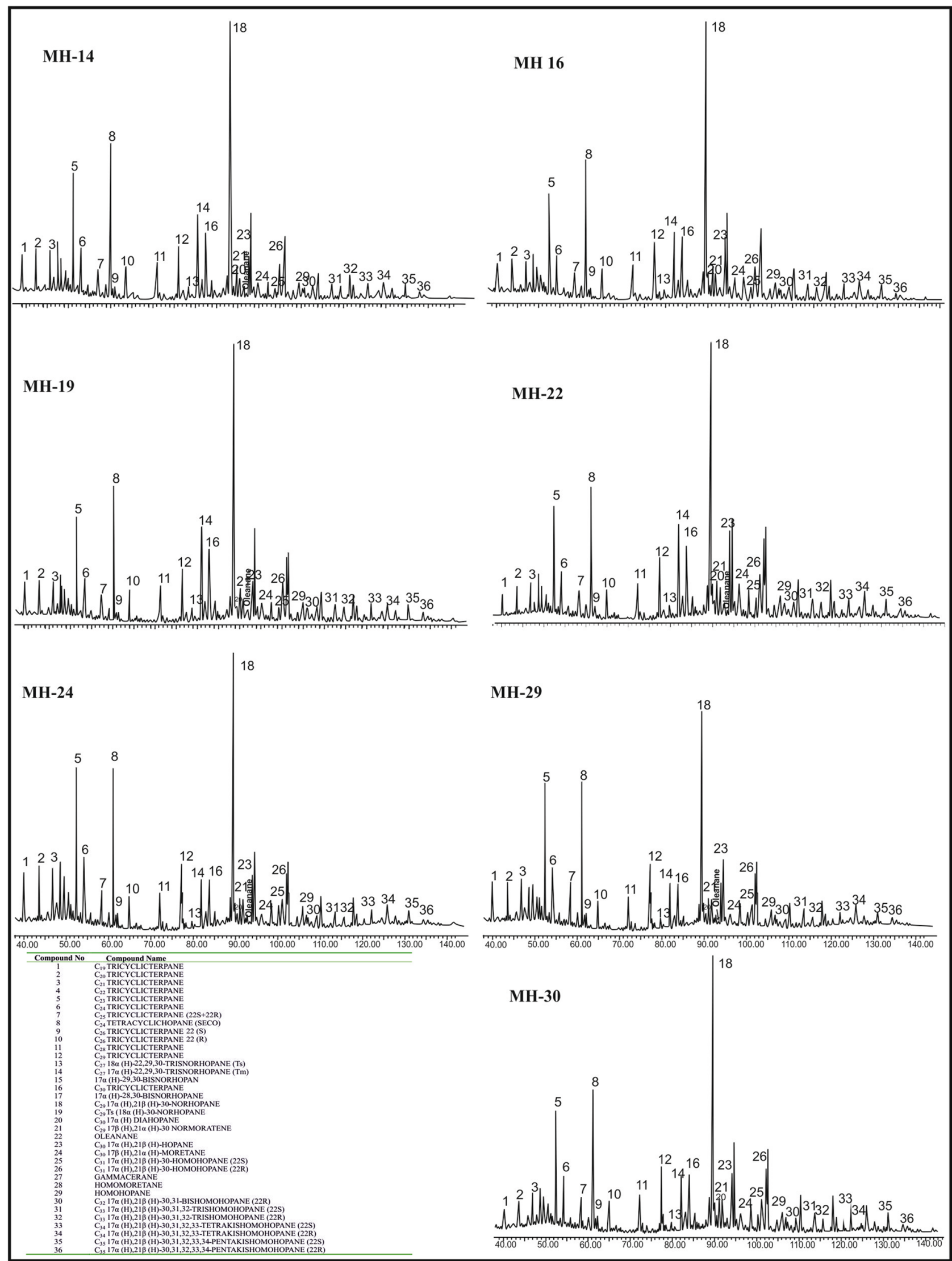

Fig. $10 \mathrm{~m} / \mathrm{z} 191$ mass chromatograms for the studied samples 
The tetracyclic terpane/hopane and tricyclic/hopane ratio increases in mature rocks and in oil because of the tetracyclic terpanes being resistant to maturation (Aquino Neto et al. 1983). These components are destroyed after hopanoids during bio-degradation, and therefore, used frequently during the correlation of the oil types that are biodegraded (Seifert and Moldowan 1980). In the investigated samples, the tetracyclic terpane/hopane ratio is between 2.35 and 3.83 , and similar results have been detected in all samples (Table 2). The normal salinity levels in Hekimhan Formation depositional conditions (30-40\%o) have been observed with pregnanes which are measured at a ratio that is close to each other in all samples (Fig. 9).

Although the Ts/(Ts $+\mathrm{Tm})$ ratios give lower values $(<1)$ in carbonate/evaporitic rocks, they are higher in rocks that are rich in silica, and in lacustrine (fresh water) or deltaic environments (>1) (Seifert and Moldowan 1980; Mello et al. 1988; Peters and Moldowan 1993). These data also indicate that the environment of formation of the samples that are analyzed is marine carbonate/evaporitic (0.11-0.13). $\mathrm{The} \mathrm{Pr} / \mathrm{Ph}$ ratio has been detected only in one sample, and indicates anoxic conditions and shale lithology. However, there is not enough data support for environmental conditions. The $\mathrm{C}_{31}-\mathrm{C}_{35}$ homohopane is used in interpreting the reduction conditions during deposition of the source rocks. This ratio has also been determined as being similar in all samples (0.12-0.15) indicating low Eh conditions (Waples and Machihara 1991) (Table 2). Low diasterane/sterane and $\mathrm{Ts} / \mathrm{Ts}+\mathrm{Tm}$ ratios define the marine deposition conditions (suboxic), like the decrease in $\mathrm{C}_{31-35}$ homohopane distribution (Peters and Moldowan 1993).

The $\mathrm{C}_{29} 20 \mathrm{~S} /(20 \mathrm{~S}+20 \mathrm{R})$ sterane ratios vary between 0.29 and 0.53 , is 0.43 in bitumen sample. $C_{29} \beta \beta /(\beta \beta+\alpha \alpha)$ sterane ratios, on the other hand, are $0.29-0.52$ and is 0.45 in the bitumen sample. The samples are distributed in early mature area in the diagram prepared according to $20 \mathrm{~S} /(20 \mathrm{~S}+20 \mathrm{R})$ sterane and $\beta \beta /(\beta \beta+\alpha \alpha)$ ratios (Table 2$)$. The $20 \mathrm{~S} /(20 \mathrm{~S}+20 \mathrm{R})$ homohopane ratio was determined as $0.40-46$ and 0.48 in the bitumen sample; and indicates early mature phase. The Tm is less sensitive when compared with Ts in catagenesis phase; and therefore, the Ts/(Ts + Tm) ratio increases with maturity (Peters et al. 2005). No clear differences were determined among the samples that were analyzed (Table 2; Fig. 10).

As it is known, the moretane/hopane ratio decreases with maturation (Seifert and Moldowan 1980; Grantham 1986; Kvenvolden and Simoneit 1990; Peters et al. 2005). The values bigger than 0.15 for this parameter indicate immature phase, which is the case in the samples that are analyzed (0.19-0.31) (Waples and Machihara 1991). In addition, according to the diahopane/ $\mathrm{C}_{29} \mathrm{Ts}(0.8-1.6), \mathrm{C}_{23}$ tricyclicterpane $/\left(C_{23}\right.$ tricyclic terpane $+C_{30}$ hopane $)(0.57-0.77)$ ratios, too, the samples that are analyzed are in immature-early mature. These data are consistent with the huminite reflection measurements $\left(0.50-0.55 \% R_{0}\right)$.

In Hekimhan formation samples, the $\boldsymbol{\delta}^{13} \mathrm{C}$ values are between $\% o-25.18$ and -23.48 , and indicate marine organic matters (Table 1). Although the isotope values of the L-2 limestone samples showed similarities, the sample with the number $\mathrm{MH}-8$, which is taken from shale and limestone levels, is a little different from the others. A $4 \%$ increase was observed in the change rate, which is $\boldsymbol{\delta}^{13} \mathrm{C}$, in $n$-alkanes with low-medium molecule in low-medium molecule weight $n$-alkanes during severe biodegradation (Stahl 1980; Mazeas et al. 2002; Sun et al. 2005). For this reason, it is possible to claim that there are no important differences in the samples in terms of isotope values, and that they are similar with the bitumen sample (Table 1).

\section{Discussion}

\section{Alteration degree of Karadere oil seep (solid bitumen)}

Physical and chemical alteration of petroleum under surface or reservoir conditions caused by bacteria is referred to as "biodegradation" (Head et al. 2003; Watson et al. 2000; Röling et al. 2006; Elias et al. 2007). Microbial/bacterial deterioration essentially develops starting from bacteria and causes chemical structures and components rich in hydrogen to dissolve. This deterioration may develop under surface conditions, as well as petroleum-water contacts in migrations and reservoirs. Washing with water, usually observed together with biodegradation, has a very little impact on the physical and chemical properties of petroleum by itself, whereas bacterial activity increases deterioration. As a result of the reduction in light components, the remaining product becomes rich in polar and aromatic components, which means a drop in the economic value for the petroleum reservoir (Head et al. 2003; Watson et al. 2000; Röling et al. 2006; Elias et al. 2007). Components in different groups such as benzene, toluene, and other aromatics disappear sequentially or simultaneously due to biodegradation (Palmer 1993; Peters et al. 1986; Elias et al. 2007). The kinetics of biodegradation is associated with the composition of the petroleum and may develop rapidly (e.g., disappearance of $n$-alkanes) or slowly (e.g., disappearance of resins and asphaltenes).

The "Biomarkers Biodegradation Scale" was defined by Volkman et al. (1983) for the first time according to the molecular compound property in oil types; and this was re-organized by Peters and Moldowan (1993) in following years. The degradation grade according to the Peters and Moldowan (1993) design is at 5th degree, qualified by the lack of $n$-alkanes and iso-alkanes. Generally, the degree/ 
level of biodegradation severity from 5th level (heavy) to 9th level (severe) as point out by variations between the biomarker compounds (Bennet and Larter 2008; Larter et al. 2003). However, it has also applications in solid bitumen as well (Dumitrescu et al. 2004; George et al. 2007). $N$-alkane is the most easily degraded group in the "Bio-degradation Scale", and the isoprenoids, hopanes, aromatic steroids and porphyries follow them (Peters and Moldowan 1993). Generally, tricyclic terpanes are more durable in chemical terms, and are degraded after hopanes and also diasteranes (Seifert and Moldowan 1980). Wenger et al. (2002) recommended a bio-degradation system that took the biomarker properties as the basis and consisted of successive steps.

As it is observed in the samples that are analyzed, the first indication of bio-degradation is the fast degradation of the single and multiple alkanes when compared with the normal alkanes, and partial or complete destruction of $\mathrm{C}_{6}-\mathrm{C}_{12}$ normal alkanes (Peters et al. 2005) (Fig. 8). Toluene, benzene and xylene are the first aromatic components to disappear from the samples due to the washing with water or bacterial activity, and are not observed in the samples that are analyzed. The majority of the $\mathrm{C}_{1}-\mathrm{C}_{5}$, $\mathrm{C}_{6}-\mathrm{C}_{15}$ components and an important part of $\mathrm{C}_{15}+$ components (about 50-55\%) do not exist in limestone and bitumen sample. Especially the long-chain $n$-alkanes, which are among the definable components, are observed at a low ratio. In addition, the detailed separations of the components in gas chromatograms being not possible, polar components with high molecular weight, and the formation of "humps" that include asphaltene are the most important markers of bio-degradation (Peters et al. 2005).

Differences are observed among the samples in terms of bio-degradation. For example, the isoprenoids being observed in GC chromatograms only in $\mathrm{MH}-14$ sample might indicate that this sample has degraded less than the other ones (Fig. 8). These data might indicate that the MH-16, -19, -29 and bitumen samples degraded more than MH-14 and -24 according to the hump height and areas in the chromatograms (Fig. 11). In addition, this interpretation is confirmed when the bio-degradation levels are compared by making use of the humps area, the humps height and $n-\mathrm{C}_{17}$ component (George et al. 2007; Permanyer et al. 2010).

Generally, since the bio-degradation in steranes $\alpha \alpha \alpha 20 \mathrm{R}>>\alpha \beta \beta 20 \mathrm{R} \geq \alpha \alpha \alpha 20 \mathrm{~S}>>$ diasteranes and $\mathrm{C}_{27}>\mathrm{C}_{28}>\mathrm{C}_{29}>\mathrm{C}_{30}, \mathrm{C}_{27}$ steranes are decreased during degradation, as in sample $\mathrm{MH}-14$, and this has led to the increase of the $\mathrm{C}_{29}$ compound in $\mathrm{MH}-14,-16$ and -19 samples. The existence of regular steranes, the $\mathrm{C}_{30}-\mathrm{C}_{35}$ hopane ratios being more than the $\mathrm{C}_{27}-\mathrm{C}_{29}$ hopanes indicate 4-5th grades, i.e., medium-high level degradation (Peters and Moldowan 1993; Peters et al. 2005; Wenger et al. 2002). Because of the tricyclic terpane, the diasteranes being not degraded yet, and the lack of 25-norhopanes, it is possible to claim that these samples have not been subject to severe biodegradation ( $>6$ th grade) (Fig. 12) (Peters et al. 2005).
Fig. 11 Correlation of degree of biodegradation for the studies samples
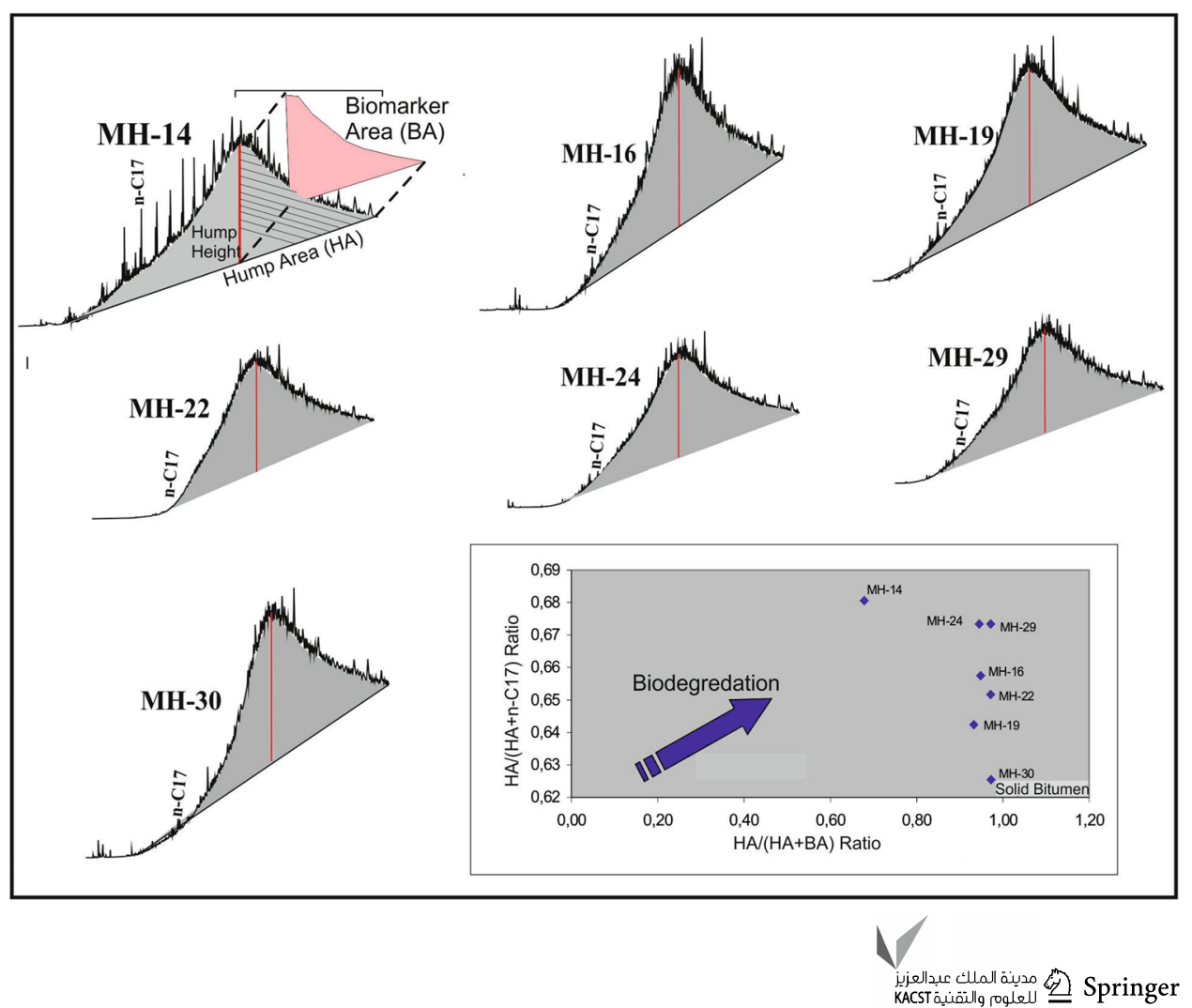


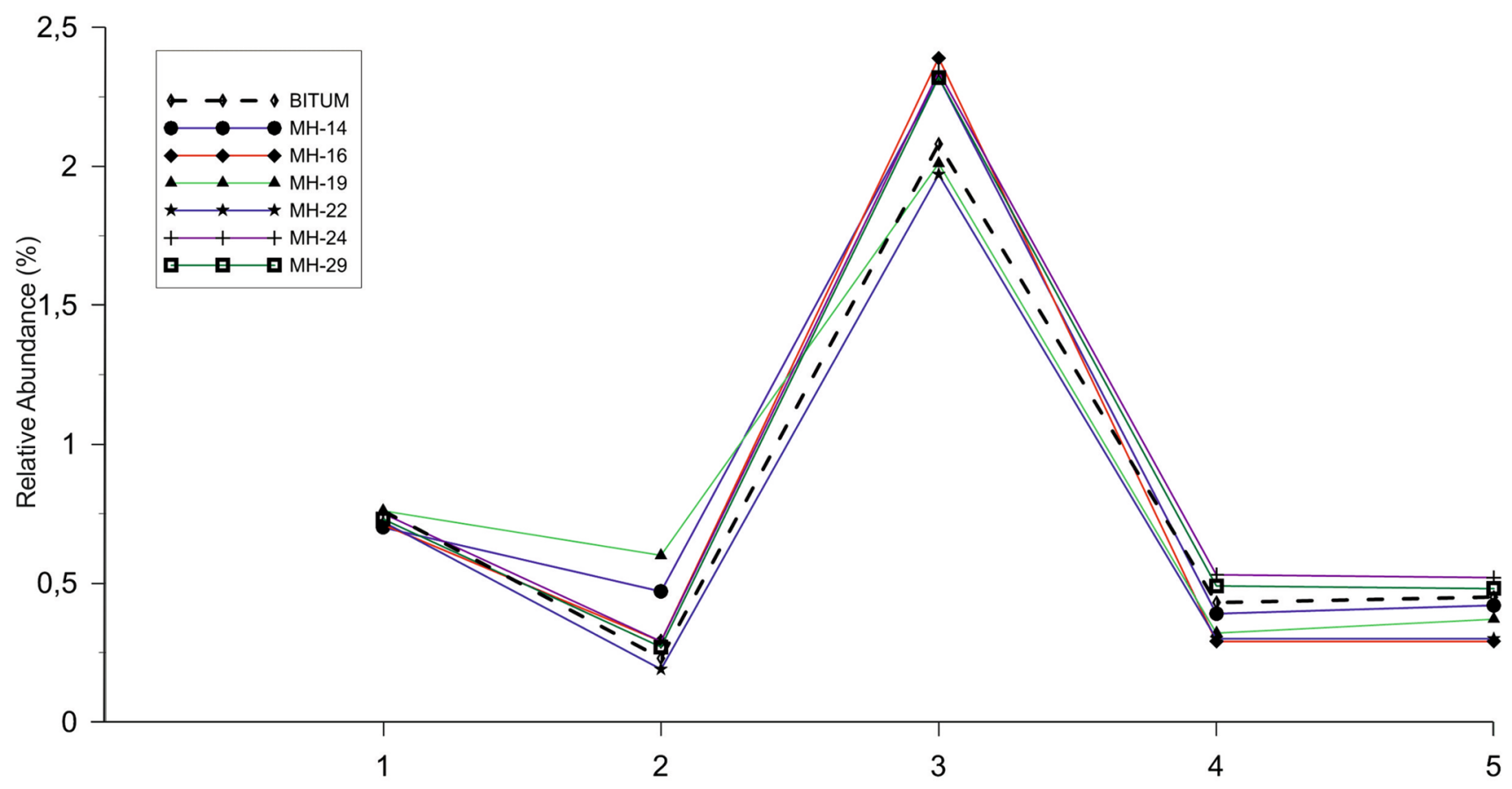

$\mathrm{X}$ Axis; $1=\mathrm{C} 28 / \mathrm{C} 29$ Steran ratio; $2=$ Diasterane/Sterane ratio; 3= Sterane/Hopane ratio; 4= C29 20S $/(20 \mathrm{~S}+20 \mathrm{R})$ ratio; $5=\mathscr{B} \mathscr{B} /(\mathscr{B} \mathscr{B}+$ aa $)$ ratio

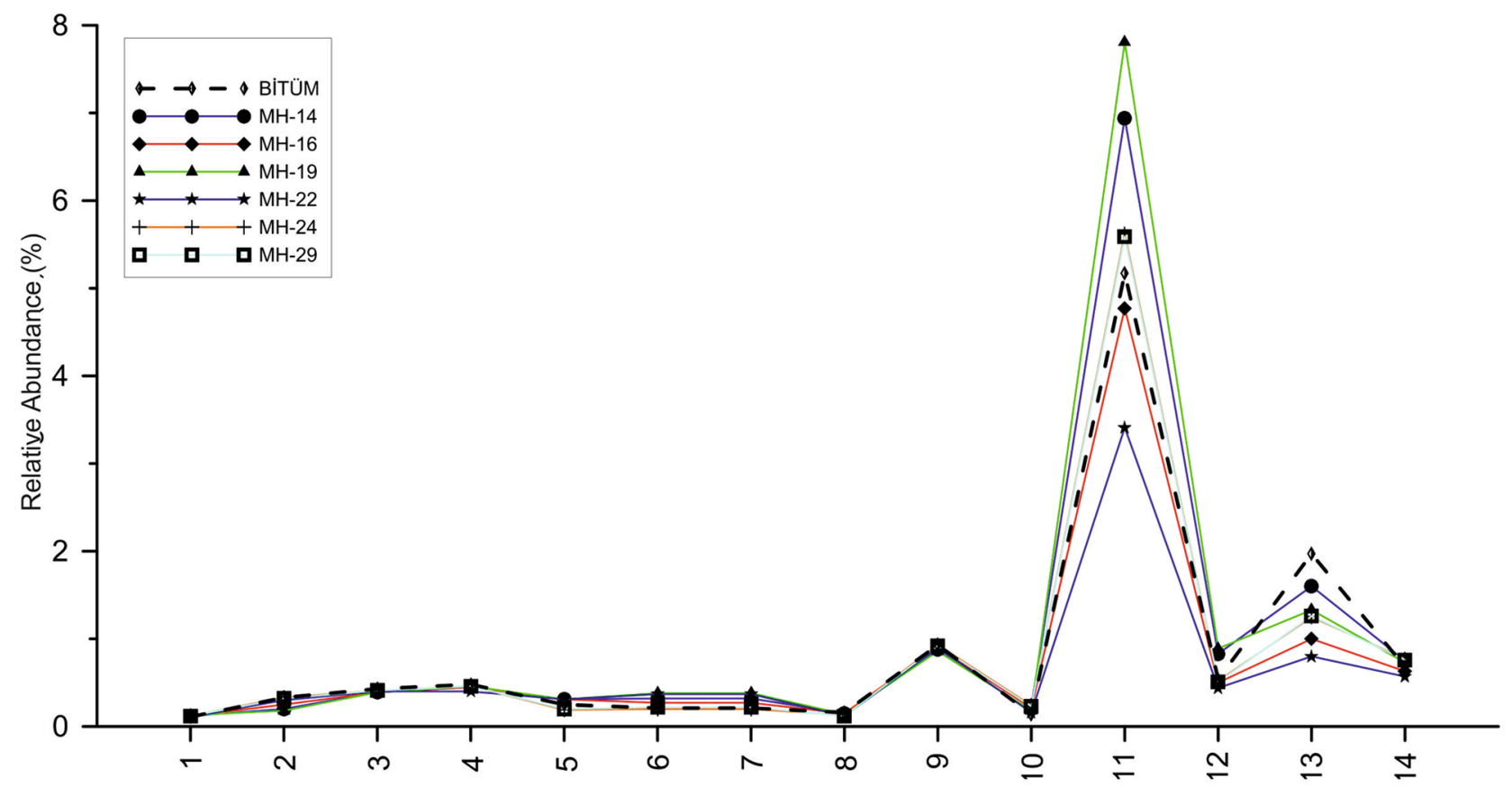

X Axis; $1=\mathrm{Ts} / \mathrm{Ts}+\mathrm{Tm}$ ratio; $2=\mathrm{C}_{26} / \mathrm{C}_{25}$ Tricyclic terpane ratio; $3=\mathrm{C}_{24} / \mathrm{C}_{23}$ Tricyclic terpan ratio; $4=\mathrm{C}_{31} 22 \mathrm{~S} /(22 \mathrm{~S}+22 \mathrm{R})$ homohopan ratio; 5=Moretane/Hopane ratio; $6=\mathrm{C}_{27} / \mathrm{C}_{29}$ Tricyclic terpane ratio; $7=\mathrm{C}_{27} / \mathrm{C}_{29}$ Tricyclic terpan ratio; $8=\mathrm{C}_{35} /\left(\mathrm{C}_{31}-\mathrm{C}_{35}\right)$ homohopane Index; 9= ETR $\left(\mathrm{C}_{28}+\mathrm{C}_{29}+\mathrm{Ts}\right) ; 10 ; \mathrm{C}_{19} / \mathrm{C}_{19}+\mathrm{C}_{23}$ Tricyclic terpane ratio; $11=$ Norhopane/hopane ratio; $12=\mathrm{C}_{31}$ homohopane/ $\mathrm{C}_{30}$ hopane ratio; 13= Diahopane $/ \mathrm{C}_{29}$ Ts ratio; $14=\mathrm{C}_{23}$ Tricyclic terpane $/ \mathrm{C}_{23}$ Tricyclic terpane $+\mathrm{C}_{30}$ hopane)

Fig. 12 Correlation diagrams of Hekimhan Formation and solid bitumen samples on the basis of sterane and terpane data 


\section{Bitumen versus source rock correlation}

The main purpose in bitumen versus source rock correlations is determining the source rock from which the bitumen has been formed and collecting information on the migration routes (Peters and Moldowan 1993). The investigations and analyses in Hekimhan formation, it has been concluded that the limestone around Karadere Village (Fig. 1a) might have the source rock potential, and that the shale and marl areas in the L-1 do not have the potential of being source rock. However, these organic wealth zones and possible source rock potential have been formed from non-indigenous hydrocarbons. For this reason, when only the parameters like TOC and hydrogen index are considered, it is clearly observed that these areas, which have or believe to have the property of being source rock, do not actually have such a potential in reality.

Generally, the steranes and terpanes obtained from the gas chromatograms or the gas chromatogram-mass spectrometer data are used commonly in oil-source rock correlations. It is more difficult to apply source rock correlation in bitumen which has been exposed to surface conditions and because of the atmospheric and bio-degradation influences being intense, which is the case in this study. The biomarker characteristics of the shale and limestone samples and the solid bitumen sample that are analyzed have been compared in detail in the following section; however, the interpretations have been made by considering the influences of the degradation in the bitumen and in the other samples and the influences of the migrated hydrocarbon.

According to biomarker data such as the sterane/hopane and diasterane/sterane ratios, the bitumen sample might have precipitated in anoxic conditions and might consists of carbonate rocks poor in clay. According to the $\mathrm{C}_{29}>\mathrm{C}_{28}>\mathrm{C}_{27}$ components in samples $\mathrm{MH}-14$ and -16, and to the $\mathrm{C}_{27}>\mathrm{C}_{28}>\mathrm{C}_{29}$ and $\mathrm{C}_{30} / \mathrm{C}_{27}-\mathrm{C}_{30}$ sterane ratios in bitumen and in the other samples, it is possible to claim that there are big similarities especially among bitumen and limestone. According to the $\mathrm{C}_{27} / \mathrm{C}_{29}$ sterane ratio, marine organic matters and marine depositional conditions are determined. According to the $n-\mathrm{C}_{15}, n-\mathrm{C}_{17}, n-\mathrm{C}_{19}$ components, the algae in lacustrine and marine environments, and the $\mathrm{C}_{19}$ and $\mathrm{C}_{20}$ components being in little amounts might be interpreted as the terrestrial and plant materials being in little amounts. However, according to the sterane/hopane ratio of the bitumen sample, high $\mathrm{C}_{35} / \mathrm{C}_{34}$ hopane ratio, low $\mathrm{C}_{24} / \mathrm{C}_{23}$ tricyclic terpane, and high $\mathrm{C}_{29} / \mathrm{C}_{30}$ hopane, $\mathrm{C}_{31} 22 \mathrm{R} / \mathrm{C}_{30}$ hopane, $\mathrm{C}_{24}$ tetracyclic terpane and norhopane, it is possible to claim that the source rock is carbonate rock. In addition, in bitumen and limestone, the distribution of $\mathrm{C}_{31}-\mathrm{C}_{35}$ homohopane is also observed in a similar status. This situation attracts attention to the similarity between the samples. Since the tricyclic terpane/hopane ratio is very low, and the gammaceran in the samples that are analyzed is not detected, it is possible that the precipitation environment might not have excessive saline or brackish water conditions. In the limestone analyzed in the bitumen sample, the biomarker data are close to each other and indicate the immature-early mature phase (Fig. 12).

Since the biomarker data, which are obtained in the bitumen sample, are similar to those of the limestone, it is possible to claim that the oil has not migrated from far areas, but is formed from the carbonates in the Hekimhan formation, and moved in the inner sides of the basin with a short-distance migration. In addition, the sterane and terpane component properties of the rocks samples show the immature hydrocarbons, and bitumen is probably a "pre-petroleum" product. These types of petroleum are the first products formed from the rocks that are rich in organic matter, and this property is defined in the solid bitumen in Ordos Basin (China) (Hanson et al. 2007).

\section{Conclusions}

The total organic carbon values varies between $\% 0.11$ and 5.92 in the grey, greenish-grey-brown shale and limestone samples in Hekimhan formation, and is extremely lower in the shales in the unit $(<0.26 \%)$, and relatively higher in the alternated limestone $(>0.50 \%)$. In the samples that are analyzed, the dominant organic matter is the amorphous (65-90\%) shales include type III kerogen while limestone samples include type II-III mixed kerogen. According to the short and medium length chain components and to $\delta^{13} \mathrm{C}$ values ( -25.18 to $-23.48 \%$ ) , the marine organic matters are dominant. According to $T_{\max }, \mathrm{PI}, R_{0}$ and biomarker data, the samples are in the immaturity level and pyrolysis data indicate that the shale samples that are analyzed do not have source rock potential; however, the limestone that are close to the seep area have this potential. However, this hydrocarbon richness reflects the pollution and non-indigenous hydrocarbon traces that are developed due to the seep (http:// www.mfa.gov.tr/turkeys-energy-strategy.en.mfa; http://www. enerji.gov.tr/en-US/Pages/Petrol).

Since the biodegradation of the Karadere oil seep (solid bitumen) and Hekimhan Formation samples, an unidentified peak group has been observed in the shape of a hump in the gas chromatogram. The bitumen samples have received bio-degradation at medium-high levels according to their $\mathrm{C}_{15}+$ components and biomarker properties. The degradation might have developed with the influence of bacteria, oxygen or surface influences. The destruction of $\mathrm{C}_{15}+$ components being destroyed at a great level makes us think that the primary oil in this area was a pre-petroleum with light properties, and that it has been transformed in the long duration and under atmosphere and reservoir conditions. In bitumen

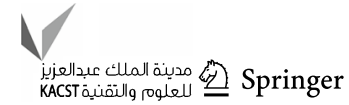


analysis, the medium-level degradation especially in light ends might have influenced heavy ends, and therefore, the interpretations have been performed not solely with these parameters but with assessing all the other data.

Biomarker and isotope components provide similarities at a great extent between the bitumen sample and the limestone in the Hekimhan Formation in the seep area. For this reason, the source of this seep has been might be the Cretaceous limestone, and detailed geochemical assessments have been made. However, it has been concluded that the Hekimhan formation limestone, which are examined in this study, do not have source rock potential, at least in the levels examined in this study, because the enrichments are based on the migrated hydrocarbons. It is assumed that some amount of oil was produced and thrown in the levels with similar lithological properties in deeper areas, and this oil has come to this area with a short-distance migration depending on the tension cracks. However, this idea will be ensured with the data that will be obtained in drilled searches in the basin and the assessments based on these data.

Acknowledgements This study was funded by the Cumhuriyet University Scientific Projects Support Fund (CUBAP; Project No: M-380). I would like to thanks Dr. Dursun ERIK (TCK) and Prof. Dr. Hüseyin YILMAZ (C.Ü) for their efforts during field trip stages of the project.

Open Access This article is distributed under the terms of the Creative Commons Attribution 4.0 International License (http://creativeco mmons.org/licenses/by/4.0/), which permits unrestricted use, distribution, and reproduction in any medium, provided you give appropriate credit to the original author(s) and the source, provide a link to the Creative Commons license, and indicate if changes were made.

\section{References}

Abrams MA (1996) Distribution of subsurface hydrocarbon seepage in near surface marine sediments. In: Schumacher D, Abrams MA (eds) Hydrocarbon migration and its near surface expressions, vol 66. Mem. Am. Ass. Petrol. Geol., Tulsa, pp 1-14

Abrams MA (2005) Significance of hydrocarbon seepage relative to petroleum generation and entrapment. Mar Pet Geol 22:457-477

Aquino Neto FR, Trendel JM, Restle A, Connan J, Albrecht PA (1983) Occurrence and formation of tricyclic and tetracyclic terpanes in sediments and petroleum. In: Bjorøy $\mathrm{M}$ et al. (eds) Advances in organic geochemistry 1981. Wiley, Chichester, pp 695-676

Ayan T (1961) Malatya kuzeyindeki Hekimhan-Ebreme köyü bölgesinin (K39 c3) detay jeolojisi ve petrol imkanları. MTA Rapor No: 4186 (unpublish) (in Turkish)

Ayyıldız T, Önal M (2005) Sedimentologic and organic geochemical properties of the Upper Cretaceous sequences in the Malatya basin, eastern Anatolia, Turkey. Inter. Earth Sciences Colloquium on the Aegean Regions-IESCA, Izmir-Turkey, October 4-7, p 14

Bennet B, Larter SR (2008) Biodegradation scales: applications and limitations. Org Geochem 39(8):1222-1228

Bhattacharya S, Dutta S (2015) Neoproterozoic-Early Cambrian biota and ancient niche: a synthesis from molecular markers and palynomorphs from Bikaner-Nagaur Basin, western India Bennet. Precambr Res 266:361-374
Booth MG, Robertson AHF, Taşlı K, İnan N (2014) Late Cretaceous to Late Eocene Hakimhan Basin (Central Eastern Turkey) as a supra-ophiolite sedimentary/magmatic basin related to later stages of closure of Neotethys. Tectonophysics 635:6-32

Buchard B, Christiansen FG, Nohr-Hansen H, Larsen NH, Ostfeldt P (1989) Composition of organic matter in source rocks. In: Christiansen FG (ed) Petroleum geology of North Greenland: Copenhagen, Grønlands Geologiske Unders $\varnothing$ gelse (GGU Bulletin 158). 92 p., pp 32-39

Clark JP, Philip RP (1989) Geochemical characterization of evaporite and carbonate depositional environments and correlation of associated crude oils in the Black Creek basin. Bull Can Pet Geol 37:401-416

Clarke RH, Cleverly RW (1991) Petroleum seepage and postaccumulation migration. In: England WA, Fleet JA (eds) Petroleum migration. Geological Society Publication, London, pp 265-271

Curiale JA (1986) Origin of solid bitumens, with emphasis on biological marker results. Org Geochem 10:559-580

Dumitrescu M, Finkelstein DB, Lazar RO, Schiber J, Brassell SC (2004) Origin and history of bitumen in geodes of the New Albany shale. In: 2004 annual field conference of the great lakes section of SEPM

Durand B, Nicaise G (1980) Procedures for kerogen isolation. In Durand B (ed) Kerogen-insoluble organic matter from sedimentary rocks. Editions Technip, Paris, pp 35-53

Dutta S, Bhattacharya S, Raju SV (2013) Biomarker signatures from Neoproterozoic-Early Cambrian oil, western India. Org Geochem 56:68-80

Elias R, Vieth A, Riva A, Horsfield B, Wilkes H (2007) Improved assessment of biodegradation extent and prediction of petroleum quality. Org Geochem 38:2111-2130

Espitalié J, Deroo G, Marquis F (1985) La pyrolyse Rock-Eval et ses applications (deuxiéme partie). Revue Institut Francais du Pétrole 40:755-784

Fink R, Virgo S, Arndt M, Visser W, Littke R, Urai JL (2016) Solid bitumen in calcite veins from the Natih Formation in the Oman Mountains: multiple phases of petroleum migration in a changing stress field. Int J Coal Geol 157:39-51

Fowler MG, Douglas AG (1984) Distribution and structure of hydrocarbons and four organic-rich Ordovician rocks. Org Geochem $6: 105-114$

George SC, Volk H, Ahmed M, Pickel W, Allan T (2007) Biomarker evidence for two sources for solid bitumens in the Subu wells: implications for the petroleum prospectivity of the East Papuan Basin. Org Geochem 38:609-642

Gonçalves PA, Mendonça Filho JG, Sobrinho da Silva F, Flores D (2015) Reprint of "Solid bitumen occurrences in the Arruda sub-basin (Lusitanian Basin, Portugal): petrographic features". Int J Coal Geol 139:217-227

Görmüş M (1992) Geological setting, fades and evolution of the Tohma reef formation, an Upper Cretaceous sequence in the Hekimhan area, NW Malatya. Türkiye 9. Petrol Kongresi Bildiriler, Jeoloji, pp 173-184

Grantham PJ (1986) Sterane isomeration and Moretane/Hopane ratios in crude oils derived from tertiary source rocks. Org Geochem 9:293-304

Gürer ÖF (1992) Hekimhan -Hasançelebi (Malatya) dolayının jeoloji incemelemesi. İ.Ü. Fen Bil. Enst. Doktora Tezi (Unpublish) (in Turkish)

Gürer ÖF, Aldanmaz E (2002) Origin of the Upper Cretaceous-Tertiary sedimentary basins within the Tauride-Anatolide platform in Turkey. Geol Mag 139(2):191-197

Hanson AD, Zhang C, Moldowan JM, Liang DG, Zhang BM (2000) Molecular organic geochemistry of the Tarim Basin, Northwest China. AAPG Bulletin 84:1109-1128 
Hanson AD, Ritts BD, Moldowan JM (2007) Organic geochemistry and thermal maturity of oils and Upper Paleozoic and Mesozoic potential source rocks in the Ordos Basin, North-Central China. AAPG Bull 91:1273-1293

Head IM, Jones DM, Larter SR (2003) Biological activity in the deep subsurface and the origin of heavy oil. Nature 426:344-352

Huc AY, Nederlof P, Debarre R, Carpentier B, Boussafir M, LaggounDéfarge F, Lenail-Chouteau A, Bordas-Le Floch N (2000) Pyrobitumen occurrence and formation in a Cambro-Ordovician sandstone reservoir, Fahud Salt Basin, North Oman. Chem Geol 168:99-112

Hunt JM (1996) Petroleum geochemistry and geology. W.H. Freeman and Company, New York

Hwang R, Teerman SC, Carlson RM (1998) Geochemical comparison of reservoir solid bitumens with diverse origins. Org Geochem 29:505-517

Jacob H (1989) Classification, structure, genesis and practical importance of natural solid bitumen ("migrabitumen"). Int J Coal Geol 11:65-79

Katz BJ (1995) The Green River Shale: an Eocene Carbonate Lacustrine Source Rock. In: Katz BJ (ed) Petroleum source rocks. Springer, Berlin

Kelemen SR, Walters CC, Kwiatek PJ, Afeworki M, Sansone M, Freund H, Pottorf RJ, Machel HG, Zhang T, Ellis GS, Tang Y, Peters KE (2008) Distinguishing solid bitumens formed by thermochemical sulfate reduction and thermal chemical alteration. Org Geochem 39:1137-1143

Kelemen SR, Walters CC, Kwiatek PJ, Freund H, Afeworki M, Sansone M, Lamberti WA, Pottorf RJ, Machel HG, Peters KE, Bolin T (2010) Characterization of solid bitumens originating from thermal chemical alteration and thermochemical sulfate reduction. Geochim Cosmochim Acta 74:5305-5332

Ketin İ (1966) Anadolu'nun tektonik birlikleri. MTA Dergisi 66:20-34 (in Turkish)

Korkmaz S, Kara-Gülbay R, Turan M (2008) Fossil fuel potential of Turkey: a statistical evaluation of reserves, production, and consumption. Energy Sour Part B 3:296-304

Kus J, Khanaqa P, Mohialdeen IMJ, Kaufhold S, Babies HG, Meßner J, Blumenberg M (2016) Solid bitumen, bituminite and thermal maturity of the Upper Jurassic-Lower Cretaceous Chia Gara Formation, Kirkuk Oil Field, Zagros Fold Belt, Kurdistan, Iraq. Int J Coal Geol 165:28-48

Kvenvolden KA, Simoneit BRT (1990) Hydrothermally derived petroleum: examples from Guaymas Basin, Gulf of California and Escanaba Trough, Northeast Pacific Ocean. AAPG Bull $74: 223-237$

Lafarquè E, Marquis F, Pilot D (1998) Rock-Eval 6 applications in hydrocarbon exploration, Production, and soil contamination studies. Revue De L'Institut Français Du Petrole 53:4

Landis CR, Castaño JR (1995) Maturation and bulk chemical properties of a suite of solid hydrocarbons. Org Geochem 22:137-149

Larter S, Wilhelms A, Head I, Koopmans M, Aplin A, Di Primio R, Zwach Z, Erdmann M, Telnaes N (2003) The controls on the composition of biodegraded oils in the deep subsurface-part 1: biodegradation rates in petroleum reservoirs. Org Geochem 34:601-613

Matsumoto G, Tori T, Hanya T (1982) High abundance of algal 24-ethylcholesterol in Antarctic lake sediment. Nature 229:52-54

Mazeas L, Budzisky H, Raymond N (2002) Absence of stable isotope fractionation of saturated and polycyclic aromatic hydrocarbons during aerobic bacterial biodegradation. Org Geochem 33:1259-1272

Mello MR, Gaglianone PC, Brassell SC, Maxwell JR (1988) Geochemical and biological marker assessment of depositional environments using Brazilian offshore oils. Mar Pet Geol 5:205-223
Moldowan JM, Seifert WK, Gallegos EJ (1985) Relationship between petroleum composition and depositional environment of petroleum source rocks. AAPG Bull 69:1255-1268

Mukhopadhyay PK, Wade JA, Kruge MA (1995) Organic facies and maturation of Jurassic/Cretaceous rocks, and possible oil-source rock correlation based on pyrolysis of asphaltenes: Scotian Basin, Canada. Org Geochem 22(1):85-104

Önal M (2009) Organic geochemical properties of marine Oligocene Unit in the Malatya Basin, East Anatolia, Turkey. Energy Sour Part A 31:1406-1414

Palmer SE (1993) Effect of biodegradation and water washing on crude oil composition. In: Engel MH, Macko SA (eds) Organic geochemistry. Plenum, New York, pp 511-533

Permanyer A, Gallego JLR, Caja MA, Dessort D (2010) Biodegradation and environmental factors at the Riutort oil shale mine, SE Pyrenees. J Pet Geol 33(2):123-140

Peters KE (1986) Guidelines for evaluating petroleum source rock using programmed pyrolysis. AAPG Bull 70:318-329

Peters KE, Moldowan JM (1993) The Biomarker guide: interpreting molecular fossils in petroleum and ancient sediments. PrenctileHall, Englewood Cliffs

Peters KE, Walters CC, Moldowan JM (2005) The biomarker guide, second edition, volume I, biomarkers and isotopes in petroleum systems and human history. United Kingdom at the Cambridge University Press, Cambridge

Petersen HI, Schovsbo NH, Nielsen AT (2013) Reflectance measurements of zooclasts and solid bitumen in Lower Paleozoic shales, southern Scandinavia: correlation to vitrinite reflectance. Int J Coal Geol 114:1-18

Röling W, Lucach FM, Larter S, Head IM (2006) Acidophilic microbial communities associated with a natural, biodegraded hydrocarbon seepage. J Appl Microbiol 101:290-299

Rullkötter J, Meyers PA, Schaefer RG, Dunham KW (1986) Oil generation in the Michigan Basin: a biological marker and carbon isotope approach. In: Leythaeuser D, Rullkötter J (eds) Advances in organic geochemistry 1985. Pergamon, Oxford, pp 359-376

Seifert WK, Moldowan JM (1980) The effect of thermal stress on source-rock quality as measured by hopane stereochemistry. In: Douglas AG, Maxwell JR (eds) Advances in organic geochemistry 1979. Pergamon, Oxford, pp 229-237

Şengör AMC, Yılmaz Y (1981) Tetiyan evolution of Turkey: a plate tectonic approach. Tectonophysics 75:181-241

Shalaby MR, Hakimi MH, Abdullah WH (2012) Geochemical characterization of solid bitumen (migrabitumen) in the Jurassic sandstone reservoir of the Tut Field, Shushan Basin, northern Western Desert of Egypt. Int J Coal Geol 100:26-39

Stahl WJ (1980) Compositional changes and 13C/12C fractionations during the degradation of hydrocarbons by bacteria. Geochim Cosmochim Acta 44:1903-1907

Sun Y, Chen Z, Xu S, Cai P (2005) Stable carbon and hydrogen isotopic fractionation of individual n-alkanes accompanying biodegradation: evidence from a group of progressively biodegraded oils. Org Geochem 36:225-238

Ten Haven HL, de Leeuw JW, Sinninghe Damsté JS, Schenck PA, Palmer SE, Zumberge JE (1988) Application of biological markers in the recognition of paleohypersaline environments. In: Kelts $\mathrm{K}$, Fleet A, Talbot M (eds) Lacustrine petroleum source rocks. Blackwell, London, pp 123-130

Tissot B, Welte DH (1984) Petroleum Formation and Occurrence. Springer, Berlin

Van der Meer F, Van Dijk P, van der Werff H, Yang H (2002) Remote Sensing and petroleum seepage: a review and case study. Terra Nova 14(1):1-17

Volkman JK, Alexander R, Kagi RI, Woodhouse GW (1983) Demethylated hopanes in crude oils and their applications in petroleum geochemistry. Geochimica et Cosmochimica Acta 47:785-794

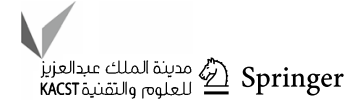


Volkman JK (1986) A review of sterol biomarkers for marine and terrigenous organic matter. Org Geochem 9:83-99

Volkman JK (1988) Biological marker compounds as indicators of the depositional environments of petroleum source rocks. In: Fleet AI, Kelts K, Talbot MR (eds) Lacustrine petroleum source rocks. Oxford, Blackwell, pp 103-122

Volkman JK, Maxwell JR (1986) Acyclic isoprenoids as biological markers. In: Larterhns RB (eds) Biological markers in the sedimentary record. Elsevier Science, Amsterdam, pp 1-42

Waple DW (1985) Geochemistry in petroleum exploration. D. Reidel Publ. Comp., Boston

Waples DW, Machihara T (1991) Biomarkers for geologists-a practical guide to the application of steranes and triterpanes in petroleum geology. AAPG Bull 9:91
Watson DF, Hindle AD, Farrimond P (2000) Organic geochemistry of petroleum seepages within the Jurassic Bencliff Grit, Osmington Mills, Dorset, UK. Petrol Geosci 6:289-297

Wenger LM, Davis CL, Isaksen GH (2002) Multiple controls on petroleum biodegradation and impact in oil quality. SPE Reserv Eval Eng 5:375-383

Publisher's Note Springer Nature remains neutral with regard tojurisdictional claims in published maps and institutional affiliations. 